ORNL/TM-2017/387

ORNL/NTRC-075, Rev. 0

\title{
Test Report of Special Form Qualification Testing for the ORNL U ZiPCAN
}

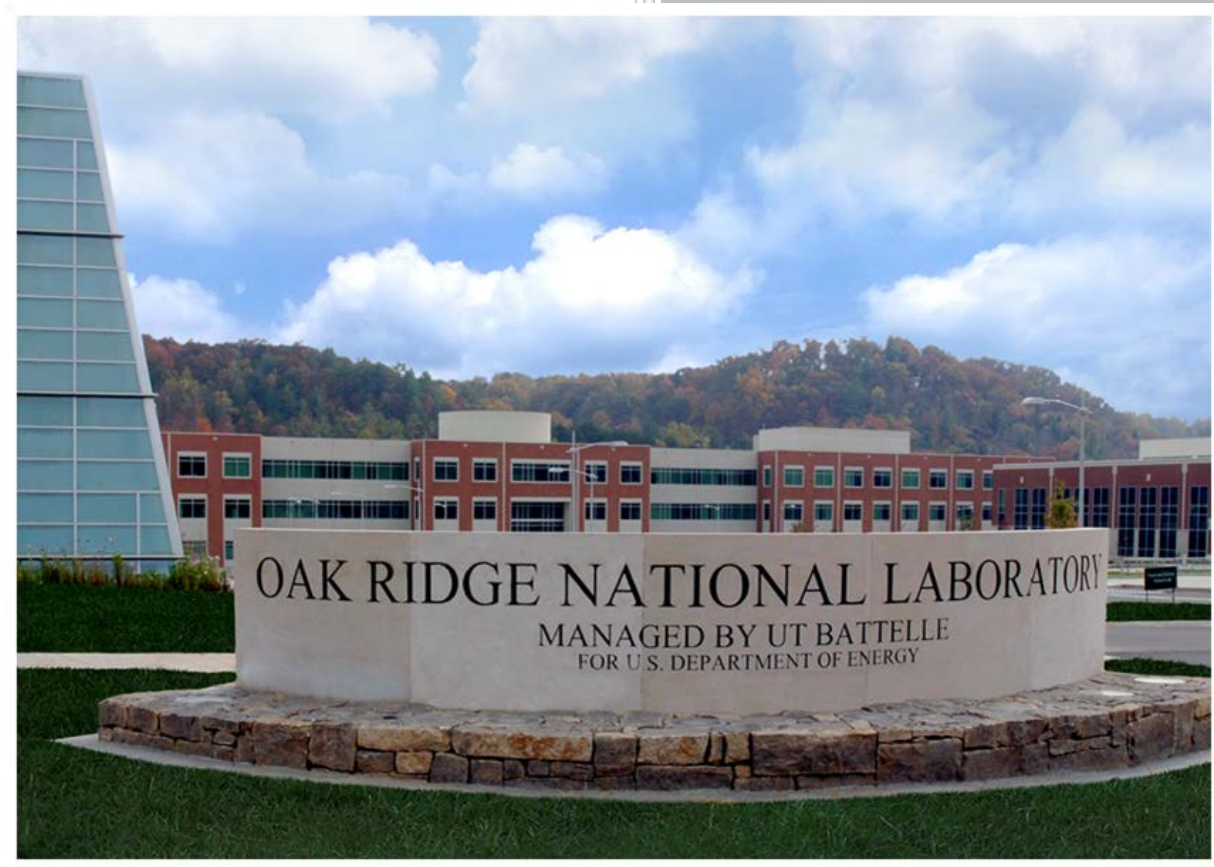

Approved for public release. Distribution is unlimited.

O. A. Martinez, Ph.D.

August 2017 


\section{DOCUMENT AVAILABILITY}

Reports produced after January 1, 1996, are generally available free via US Department of Energy (DOE) SciTech Connect.

Website http://www.osti.gov/scitech/

Reports produced before January 1, 1996, may be purchased by members of the public from the following source:

National Technical Information Service

5285 Port Royal Road

Springfield, VA 22161

Telephone 703-605-6000 (1-800-553-6847)

TDD 703-487-4639

Fax 703-605-6900

E-mail info@ntis.gov

Website http://classic.ntis.gov/

Reports are available to DOE employees, DOE contractors, Energy Technology Data Exchange representatives, and International Nuclear Information System representatives from the following source:

Office of Scientific and Technical Information

PO Box 62

Oak Ridge, TN 37831

Telephone 865-576-8401

Fax 865-576-5728

E-mail reports@osti.gov

Website http://www.osti.gov/contact.html

This report was prepared as an account of work sponsored by an agency of the United States Government. Neither the United States Government nor any agency thereof, nor any of their employees, makes any warranty, express or implied, or assumes any legal liability or responsibility for the accuracy, completeness, or usefulness of any information, apparatus, product, or process disclosed, or represents that its use would not infringe privately owned rights. Reference herein to any specific commercial product, process, or service by trade name, trademark, manufacturer, or otherwise, does not necessarily constitute or imply its endorsement, recommendation, or favoring by the United States Government or any agency thereof. The views and opinions of authors expressed herein do not necessarily state or reflect those of the United States Government or any agency thereof. 
ORNL/2017/387

ORNL/NTRC-075

Rev. 0

Reactor and Nuclear Systems Division

\title{
TEST REPORT OF SPECIAL FORM QUALIFICATION TESTING FOR THE ORNL U ZIPCAN
}

\author{
O. A. Martinez, Ph.D.
}

August 2017

Prepared by

OAK RIDGE NATIONAL LABORATORY

Oak Ridge, TN 37831-6285

managed by

UT-BATTELLE, LLC

for the

OAK RIDGE NATIONAL LABORATORY

Nuclear Security and Isotope Technology Division

US DEPARTMENT OF ENERGY

under contract DE-AC05-00OR22725 



\section{REVISION LOG}

\begin{tabular}{|l|l|l|l|}
\hline \multicolumn{1}{|c|}{ Revision \# } & \multicolumn{1}{|c|}{ Issue Date } & \multicolumn{1}{c|}{ Pages affected } & \multicolumn{1}{c|}{ Comments } \\
\hline Revision 0 & August 2017 & All & Original Issue \\
\hline & & & \\
\hline & & & \\
\hline & & & \\
\hline
\end{tabular}





\title{
Test Report of Special Form Qualification Testing for the ORNL U ZiPCan
}

\author{
Prepared for \\ Oak Ridge National Laboratory \\ Nuclear Security and Isotope Technology Division \\ Prepared by \\ O. A. Martinez, Ph.D. \\ Oak Ridge National Laboratory \\ Reactor and Nuclear Systems Division \\ Used Fuel Systems Group \\ at the \\ National Transportation Research Center
}

APPROVALS

Name

Position

Date

O A. Martinez, Ph.D. ORNL Package Testing Program

Matt Feldman, P.E. $\quad$ ORNL Package Testing Program Manager

Michael Houston ORNL Package Testing Quality Representative

John Scaglione Used Fuel System Group Leader 



\section{CONTENTS}

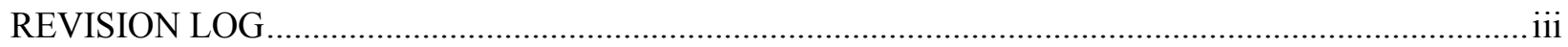

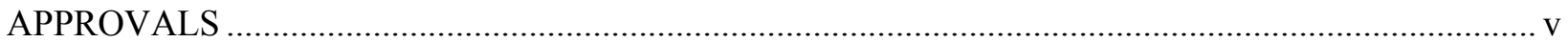

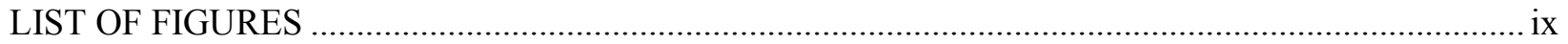

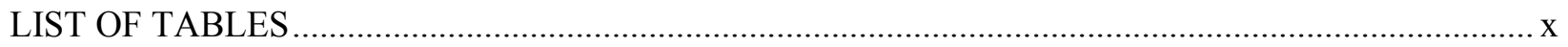

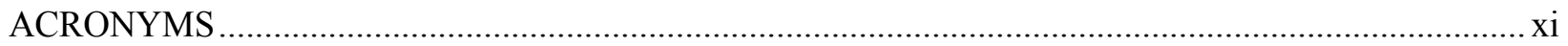

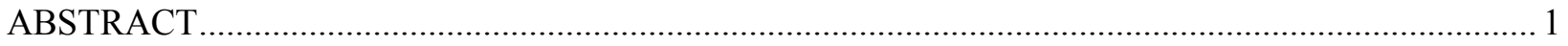

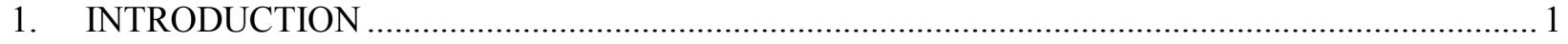

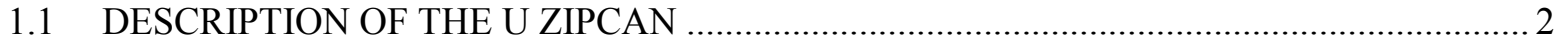

1.2 DESCRIPTION OF QUALITY ASSURANCE ACTIVITIES …..................................... 4

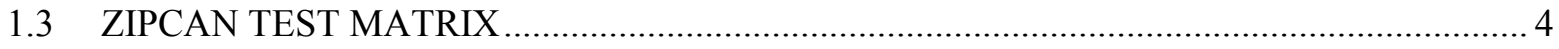

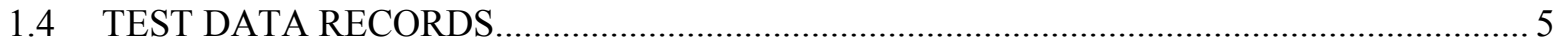

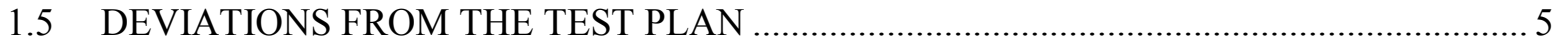

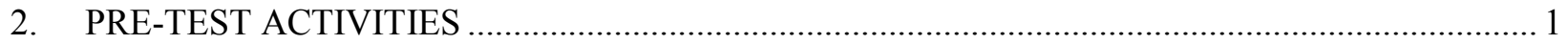

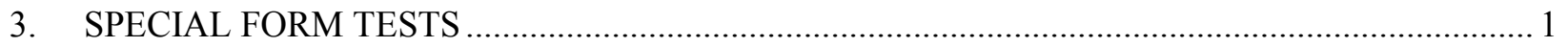

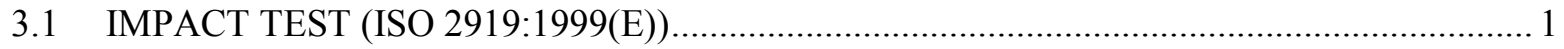

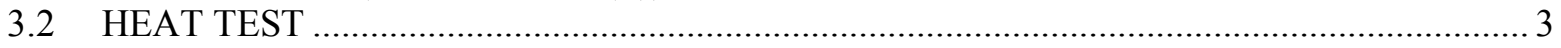

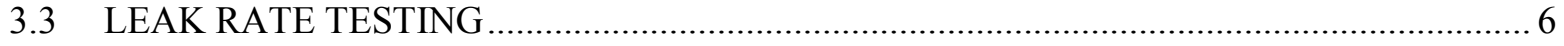

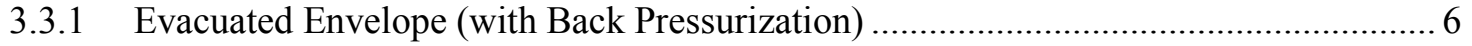

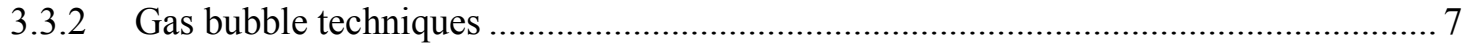

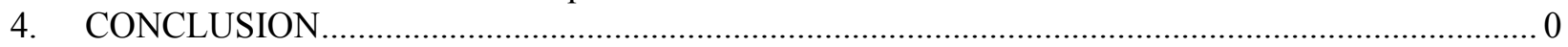

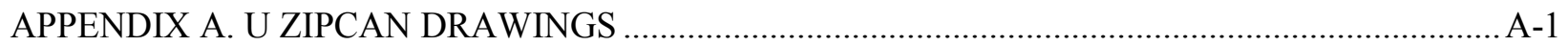

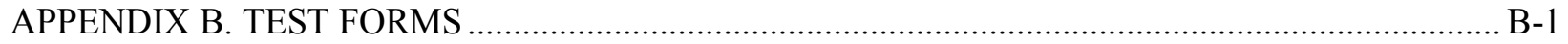

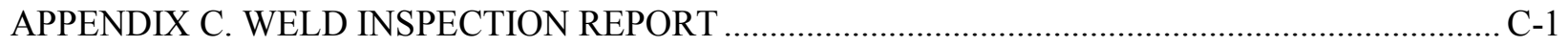

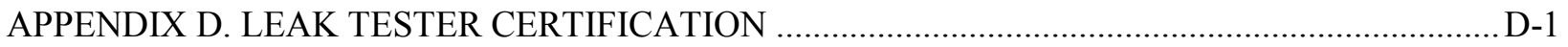

APPENDIX E. LEAK TESTING PROCEDURE ….............................................................. E-1

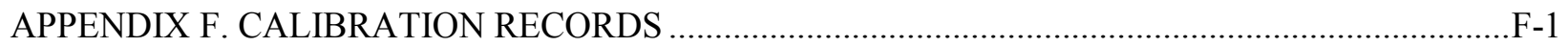





\section{LIST OF FIGURES}

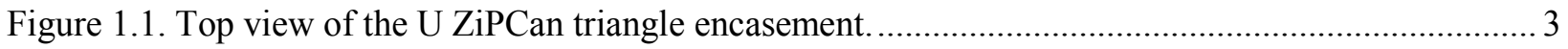

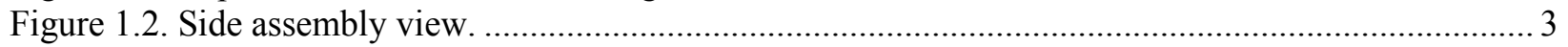

Figure 1.3. U ZiPCan triangle encasement test unit................................................................. 4

Figure 3.1. Impact billet $1 \mathrm{~m}$ above the ZiPCan. ................................................................................. 2

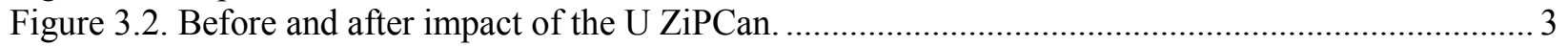

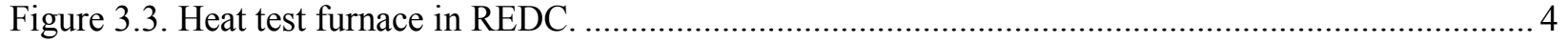

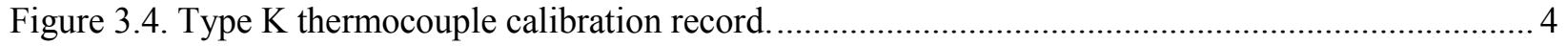

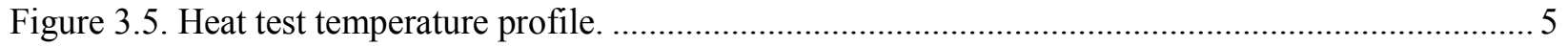

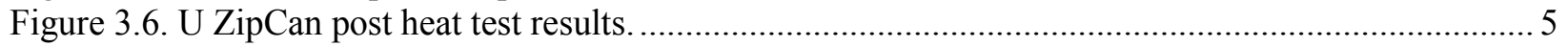

Figure 3.7. Diagram of helium back pressurization test. ….................................................................. 7

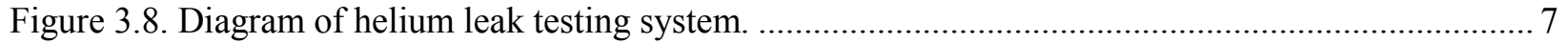

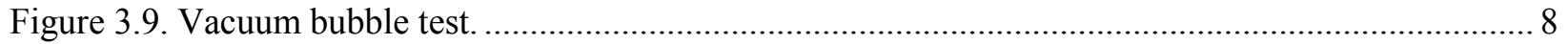

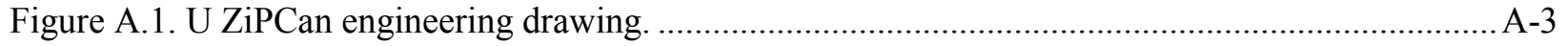




\section{LIST OF TABLES}

Table 1.1. Isotopic distribution of the heat test unit, TU-1 (C1-0290) .................................................. 3

Table 1.2. Sequence of Tests and Processes for the U ZiPCan............................................................. 5

Table 1.3. Detailed sequence of tests and processes for Test Units 1-3 (TU-1 through TU-3) ................. 5

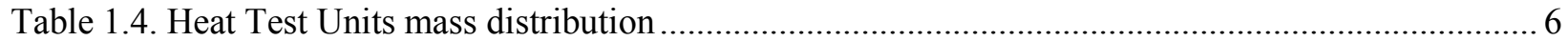

Table 3.1. Leak rate test variables and results for TU-1 and TU-4 .................................................... 8

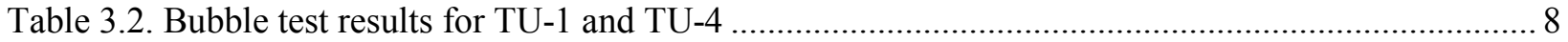




\section{ACRONYMS}

$\begin{array}{ll}\text { ANSI } & \text { American National Standards Institute } \\ \text { ASTM } & \text { American Society for Testing and Materials } \\ \text { CFR } & \text { Code of Federal Regulations } \\ \text { NDT } & \text { non-destructive testing } \\ \text { NSC } & \text { Y-12 National Security Complex } \\ \text { ORNL } & \text { Oak Ridge National Laboratory } \\ \text { PTP } & \text { Package Testing Program } \\ \text { QA } & \text { quality assurance } \\ \text { REDC } & \text { Radiochemical Engineering Development Center } \\ \text { RHAC } & \text { Research Hazard Assessment and Control } \\ \text { TIG } & \text { tungsten inert gas } \\ \text { TU } & \text { test unit } \\ \text { ZiPCans } & \text { Zirconia Pre-Encapsulation Canisters }\end{array}$




\begin{abstract}
Two prototype Zirconia Pre-Encapsulation Canisters (ZiPCans) of the same design were evaluated to demonstrate compliance with requirements of the following regulations:

- Title 49, Code of Federal Regulations (CFR), Part 173.469, Tests for Special Form Class 7 (Radioactive) Materials, and

- Title 10, Code of Federal Regulations, Part 71.75 (1)(i), Qualification of special form radioactive material and ISO2919:1999(E) Radiological protection -Sealed radioactive sources - General requirements and classification.

The results of the special form tests are documented in this test report.

This test report describes the special form testing activities performed on the two ZiPCans. One prototype test unit was subjected to the tests stipulated by 10 CFR 71.75 (d)(1)(i), ISO 2919:1999(E) Class 4 impact test, along with the leak rate test specified in 49 CFR 173.469(a)(4)(i). The other test unit was subjected to a leak rate test as specified in 173.469(a)(4)(i) and a heat test as specified in 49 CFR 173.469 (b)(4). Each test unit was leak tested before and after these respective tests. The leak rate tests performed were helium back-pressure tests and bubble tests, as specified in ANSI N14.5-2014. The measured leak rates were converted to standard condition leak rates as specified in ASTM E 493. The determined standardized leak rates from the test and calculation for both test units met the requirements for special form certification.

The testing was performed by or under the direction of the Oak Ridge National Laboratory (ORNL) Package Testing Program (PTP).
\end{abstract}

\title{
1. INTRODUCTION
}

Two prototype ZiPCans designed to contain uranium (henceforth referred to as U ZiPCans), were tested to demonstrate compliance with the requirements of

- $\quad$ Title 49, Code of Federal Regulations (CFR), Part 173.469, Tests for Special Form Class 7 (Radioactive) Materials, and

- Title 10, Code of Federal Regulations, Part 71.75, Qualification of special form radioactive material and ISO2919:1999(E) Radiation protection -Sealed radioactive sources - General requirements and classification.

These prototypes served as test units and are identified as TU-1 (C1-0290), and TU-4 (OPSF1).

The 10 CFR 71.75 requirement states:

(d) A specimen that comprises or simulates radioactive material contained in a sealed capsule need not be subjected to -

(1) The impact test and the percussion test of this section, provided that the specimen is:

(i) Less than 200 grams and alternatively subjected to the Class 4 impact test prescribed in ISO 2919:1999(E) "Radiation protection -Sealed radioactive sources - General requirements and classification” 
Since the ZipCan design is less than $200 \mathrm{~g}$, the TU-4 U ZiPCan was subjected to a Class 4 impact test only as prescribed in ISO2919:1999(E) in lieu of the percussion and impact test described in 49 CFR 176.469 (b).

The ISO2919:1999(E) impact test is specified below:

\subsection{Impact Test}

\subsubsection{Apparatus}

7.4.1.1 Steel hammer, the upper part of which is equipped with a means of attachment, and the lower part of which shall have an external diameter of (25 \pm 1$) \mathrm{mm}$ and a flat striking surface with its outer edge rounded to a radius of (3.0 \pm 0.3$) \mathrm{mm}$.

The center of gravity of the hammer shall lie on the axis of the circle, which defines the striking surface; this axis itself passing through the point of attachment. The mass of the hammer for each test class is given in Table 2.

7.4.1.2 Steel anvil, the mass of which is at least ten times that of the hammer. It shall be rigidly mounted so that it does not deflect during impact and shall have a flat surface, large enough to support the entire sealed source.

According to Table 2 from ISO 2919:1999(E), the weight of the steel hammer for the Class 4 impact test shall be " $2 \mathrm{~kg}$ from $1 \mathrm{~m}$ or equivalent imparted energy." Based on the equation of potential energy to total imparted energy, the imparted energy shall be $19.61 \mathrm{Joules}=2 \mathrm{~kg} \times 9.81 \mathrm{~m} / \mathrm{s}^{2} \times 1 \mathrm{~m}$. Additionally, TU-4 subsequently was subjected to a leak rate test before and after each of the tests described above to determine test outcome, as follows:

Leak Rate Test (49 CFR 173.469 (a)(4)(i))

Demonstration of leak tightness of $10^{-4}$ torr $-1 / \mathrm{s}\left(3.1 \times 10^{-4} \mathrm{~atm}-\mathrm{cm}^{3} / \mathrm{s}\right)$ based on air at $25^{\circ} \mathrm{C}\left(77^{\circ} \mathrm{F}\right)$ and one atmosphere differential for solid radioactive content . .

TU-1 underwent one heat stress test, as well as leak rate testing, as described above, before and after the heat stress test:

Heat Stress Test (49 CFR 173.469 (b)(4)):

The specimen must be heated in air to a temperature of not less than $800^{\circ} \mathrm{C}$ $\left(1475^{\circ} \mathrm{F}\right)$, held at that temperature for a period of 10 minutes, and then allowed to cool.

All tests (impact test, heat stress tests, and leak rate tests) were performed by or under the direction of the Oak Ridge National Laboratory (ORNL) Package Testing Program (PTP). This report provides a detailed description of the test methodologies and results.

\subsection{DESCRIPTION OF THE U ZIPCAN}

The inner container of the U ZiPCan is a titanium triangular assembly with four threaded $3 / 32$-inch fill holes over four inner triangular cavities matted with a 0.05 -inch thick zirconium oxide felt. Uranium heat stress test unit (TU-1) was manufactured by depositing drops of a nitrate solution into the inner triangular 
cavities through the fill holes. After the solution was deposited, the filled triangular assembly was slowly heated to concentrate the liquid to a dry salt and then was subsequently fired in a furnace to convert the uranium material to an oxide. Four titanium screws were then inserted into the threaded fill holes. The assembly was then placed in a stainless steel triangular encasement, and fitted with a lid which had been welded with a tungsten inert gas (TIG) arc welder. The U ZiPCan is shown in parts in Figure 1.1 and Figure 1.2, and the impact test unit is shown in Figure 1.3.

A loaded U ZiPCan containing a maximum of $3.2 \mathrm{~g}$ (element weight) of uranium oxide was used for the heat test, and an unloaded ZiPCan was used for the impact test. The isotopic distribution of TU-1 is shown below.

Table 1.1. Isotopic distribution of the heat test unit, TU-1 (C1-0290)

\begin{tabular}{lc||ccc}
\hline \multicolumn{5}{c}{ ORNL U ZiPCan load information } \\
\hline Tile/serial No. & $\mathrm{C} 1-0290$ & & Weight, $\mathbf{g}$ & Weight, fraction \\
Total weight & $35.783 \mathrm{~g}$ & ${ }^{234} \mathbf{U}$ & $3.146 \mathrm{E}-05$ & $9.831 \mathrm{E}-06$ \\
$\mathbf{U O}_{3} / \mathbf{U}_{3} \mathbf{O}_{\mathbf{8}}$ weight & $4.58 \mathrm{~g}$ & ${ }^{235} \mathbf{U}$ & $1.295 \mathrm{E}-03$ & $4.048 \mathrm{E}-04$ \\
Uranium weight & $3.2 \mathrm{~g}$ & ${ }^{236} \mathbf{U}$ & $3.173 \mathrm{E}-05$ & $9.916 \mathrm{E}-06$ \\
Isotopic mass date & $3 / 23 / 2017$ & ${ }^{238} \mathbf{U}$ & $3.199 \mathrm{E}+00$ & $9.996 \mathrm{E}-01$ \\
\hline
\end{tabular}

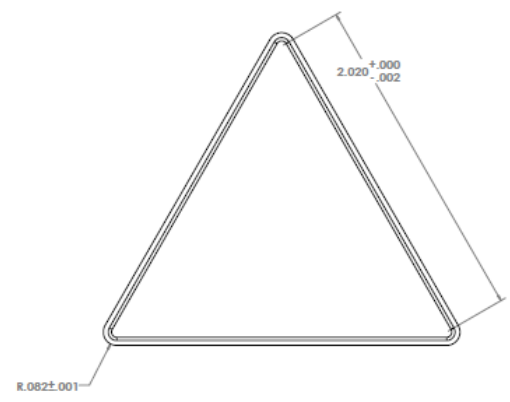

Figure 1.1. Top view of the U ZiPCan triangle encasement.

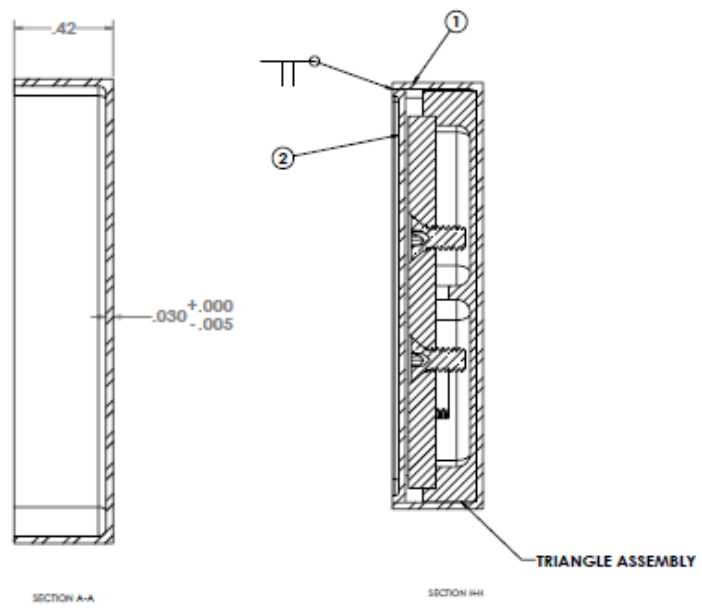

Figure 1.2. Side assembly view. 


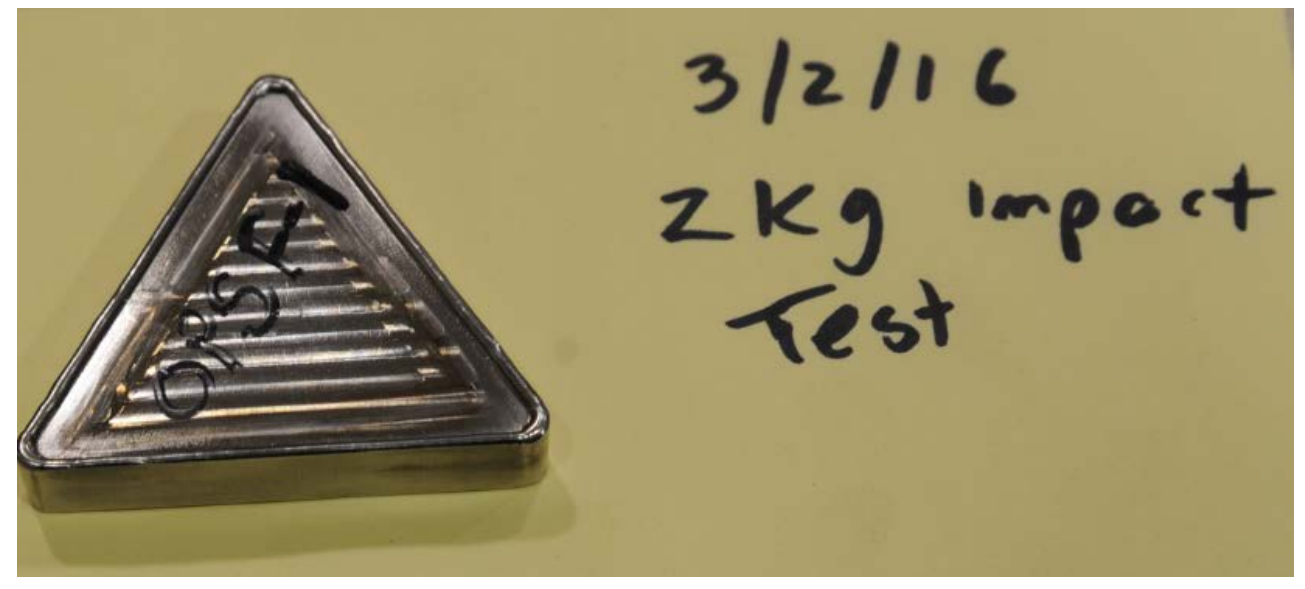

Figure 1.3. U ZiPCan triangle encasement test unit.

\subsection{DESCRIPTION OF QUALITY ASSURANCE ACTIVITIES}

All DOE contractors are required by contract with the US Government to comply with DOE Order 414.1D, 10 CFR 830.120 and/or other specific quality assurance (QA) requirements. Specific QA programs apply to each of three primary phases of effort (design, manufacture, and certification testing). ORNL was responsible for the design process, and the applicable QA program is the ORNL Quality Management System, Quality Assurance Program Description. The Radiochemical Engineering Development Center at ORNL was responsible for all manufacturing activities, and the two applicable QA programs are the Quality Management System described in NMP-QM-1, Rev. 1, Quality Manual for the Nuclear Material Processing Group, and the Nonreactor Nuclear Facility Division NNFD-017-C, Rev. 1, NNFD Fabrication Control Procedure.

For the certification testing process, each test was conducted in accordance with ORNL/NTRC-074 entitled Test Plan for the Special Form Qualification Testing of the U ZiPCan Triangle Encasement (available upon request) and the appropriate procedures listed in the test plan. The QA aspects of activities in the test plan are controlled by the PTP QA requirements of 10 CFR 830.122. The safety aspects of activities in this test plan are controlled by the ORNL Research Hazard Assessment and Control (RHAC) Research Safety Summary (RSS) 1082, titled General Use and Package Testing Activities Conducted in the NTRC Packaging Research Facility. Additionally, all testing performed by PTP is conducted under the QA plan outlined in NTRC-PRF-QAP-001, Rev. 2, Quality Assurance Plan for the Package Testing Program.

\subsection{ZIPCAN TEST MATRIX}

TU-1 is a U ZiPCan loaded with $3.2 \mathrm{~g}$ of uranium Table 1.2 provides the sequence of the tests and processes performed on each test unit. The number in the cell indicates the sequence in which the process or test was performed on the test unit. TU-4 is a U ZiPCan without radioactive material. It was deemed that the radioactive material provided a negligible amount of support to the titanium structure. The weight added is also irrelevant due to substitution of the ISO class for impact test as applicable to the drop test. 
Table 1.2. Sequence of Tests and Processes for the U ZiPCan

\begin{tabular}{lcc}
\hline \multirow{2}{*}{ Test or process description } & \multicolumn{2}{c}{ Test unit } \\
\hline Leak test & TU-1 (C1-0290) & TU-4 (OPSF1) \\
Impact test (ISO 2919) & 1 & 1 \\
Heat test & - & 2 \\
Leak test & 2 & - \\
\hline
\end{tabular}

\subsection{TEST DATA RECORDS}

This report documents the tests performed and measurements observed from the U ZiPCan testing. The general data types for these tests are:

- manually derived measurements and observations,

- digital still photography, and

- video recording of the drop and percussion tests.

The primary recording media for each of the general types of data are:

- procedure checklists, data sheets and test forms for data, measurements, and observations,

- computer files (JPG format) of the digital photography, and

- computer files (MPG format) of the video recordings.

The completed data sheets and procedure checklists have been scanned into a digital format and are available upon request. Photographs are presented in the main body of this document as appropriate.

\subsection{DEVIATIONS FROM THE TEST PLAN}

Per the test plan (ONRL/NTRC-074), 3 test units were subjected to the preheat leak test and a heat test.

Table 1.3 provides a detailed sequence for the tests conducted on Test Units TU-1, TU-2 and TU-3.

Table 1.3. Detailed sequence of tests and processes for Test Units 1-3 (TU-1 through TU-3)

\begin{tabular}{ll}
\hline $\begin{array}{c}\text { Test Unit TU-1, TU-2, TU-3 } \\
\begin{array}{c}\text { Sealed encapsulated specimen } \\
\text { with radioactive material (U) }\end{array}\end{array}$ & \multicolumn{1}{c}{ Acceptance criteria } \\
\hline Test sequence \#1: Leaktightness & $\begin{array}{l}\text { Leak Test - 49 CFR 173.469 (a)(4)(i) })^{a, b, c} \\
\text { Leak pretest to ensure that there is no leakage prior to performance of } \\
\text { heat test. }\end{array}$ \\
Test sequence \#2: Heat test & $\begin{array}{l}\text { Heat Test - 49 CFR 173.469 (b)(4): The specimen may not melt or } \\
\text { disperse when subjected to the heat test }\end{array}$ \\
Reference 49 CFR 173.469 (a)(3) & $\begin{array}{l}{ }^{a} \\
\text { Leak Test - 49 CFR 173.469 (a)(4)(i) })^{a, b, c} \\
\text { Leakage post-test to ensure that there is no leakage after heat test. }\end{array}$ \\
\hline
\end{tabular}

${ }^{a}$ After each test, leaktightness of the specimen must be determined. Reference 49 CFR173.469(a)(4).

$\boldsymbol{b}$ Perform test for leaktightness per 49 CFR 173.469 (a) (4) (i). NOTE: The test specimen capsule must be fabricated from corrosion-resistant material that is resistant to corrosion by water and must have an internal void volume greater than 0.1 millimeters. Leaktightness testing acceptance criteria must demonstrate a leak tightness of $10^{-4}$ torr- $1 / \mathrm{s}\left(1.3 \times 10^{-4} \mathrm{~atm}-\mathrm{cm}^{3} / \mathrm{s}\right)$ based on air at $25^{\circ} \mathrm{C}\left(77^{\circ} \mathrm{F}\right)$ and one atmosphere differential pressure for solid radioactive content. This test method is more sensitive than the leaching assessment methods specified by 49CFR 173.469 (4)(c).

${ }^{c}$ Leaching assessment methods for indispersible solid material do not apply. Reference 49 CFR 173.469 (4)(i). 
Table 1.4 shows data for the test units that were subjected to the heat test with the corresponding weigh of radioactive material. The post leak test was first performed on the heavy test unit (C1-0290), and that test unit passed the leak test; therefore, leak tests were not performed for the remaining heat test units because the leak test results for the $3.2 \mathrm{~g}$ test unit will cover the $2.5 \mathrm{~g}$ and $1.7 \mathrm{~g}$ test unit. This test report only reports the leak test results and heat test results of the $3.2 \mathrm{~g}$ test unit (C1-0290).

Table 1.4. Heat Test Units mass distribution

\begin{tabular}{ccc}
\hline Test unit SN & Test unit number & Uranium weight (g) \\
\hline C1-0290 $1-0288$ & 1 & 3.2 \\
C1-0289 & 2 & 2.5 \\
\end{tabular}




\section{PRE-TEST ACTIVITIES}

The test units were delivered for testing in a ready-to-test condition, so there were no specific pretest activities. 


\section{SPECIAL FORM TESTS}

Special form testing requirements are specified in 49 CFR 173.469 (b), 10 CFR 71.75, and ISO 2919:1999(E). For this design, three tests were required: the Class 4 impact test per ISO 2919:1999(E), a heat test, and a leak test. The bending test was not required because the length-to-width ratio of the design is not greater than 10. After each test, each test unit was subjected to a helium leakage rate test and a bubble test as specified in 49 CFR 173.469(a). Each test performed and the results of these tests are described below.

\subsection{IMPACT TEST (ISO 2919:1999(E))}

Test unit 4, TU-4 (OPSF1) was subjected to the ISO 2919:1999(E) Class 4 impact test, which was carried out at the indoor drop pad located at the National Transportation Research Center in Knoxville, Tennessee. This drop pad has a total mass of $\sim 13.6$ metric tons and meets the specifications for the impact test target according to the Design and Certification of Targets for Drop Testing at the NTRC Package Research Facility Rev. 0, May 2003, ORNL/NTRC-001. The test was performed according to the procedure outlined in the Test Plan for the Special Form Qualification Testing of the U ZiPCan Triangle Encasement, ORNL/NTRC-074, Section 3.7.1. Testing activities and results were recorded on Test Form 1 from the test plan.

The TU-4 U ZiPCan was centered on the indoor drop pad. A 1-inch diameter steel billet, weighing $2 \mathrm{~kg}$ was placed on the release mechanism and raised to a height of 1 meter. A calibrated meter stick was used to measure the height from the bottom surface of the billet to the top surface of the U ZiPCan (Figure 3.1). When ready, the steel billet was released so that the billet made a direct impact on the vertex of TU4. 


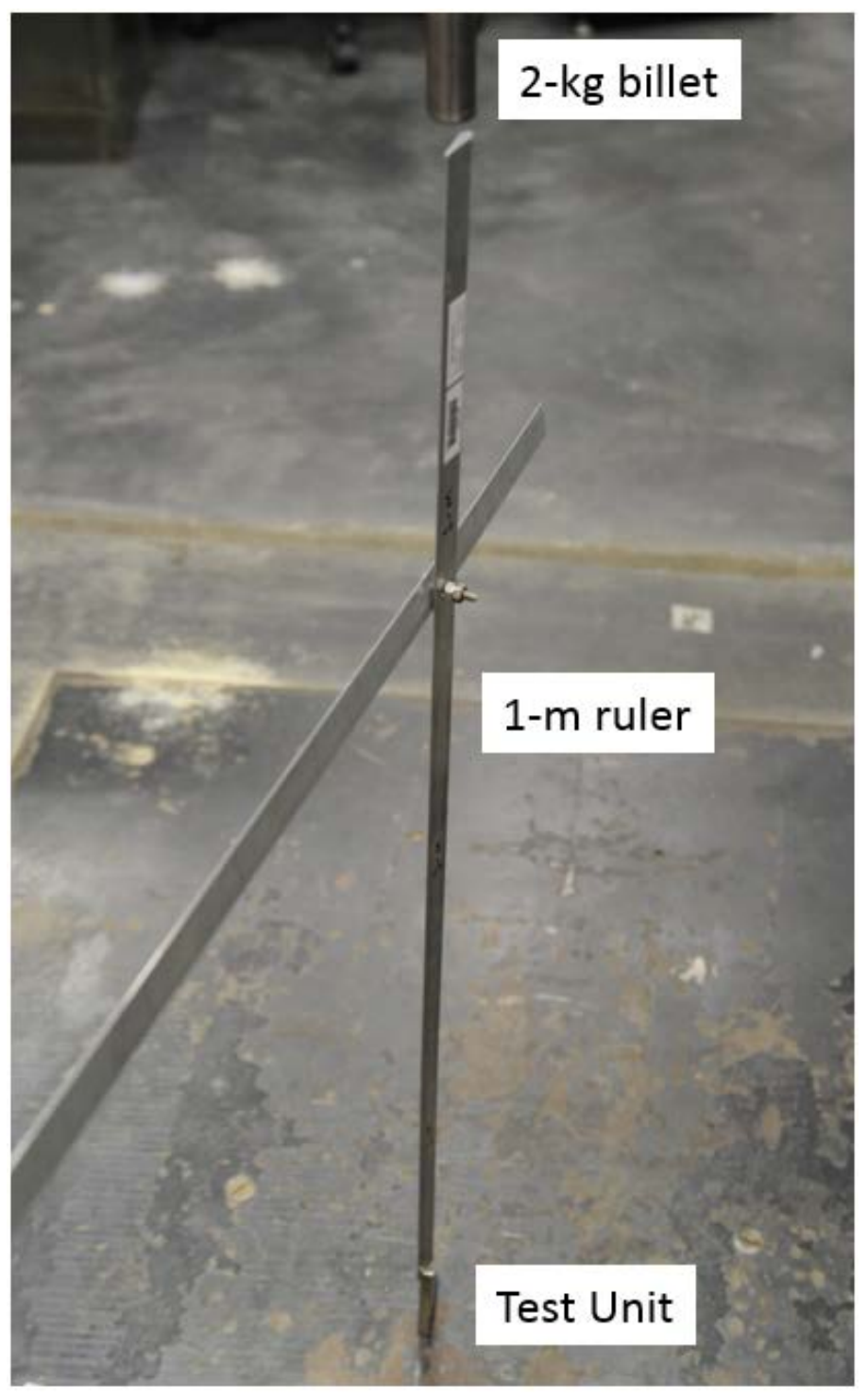

Figure 3.1. Impact billet $1 \mathrm{~m}$ above the ZiPCan.

When released, the billet appeared to impact TU-4 squarely on the vertex. The impact of the billet resulted in a slight indentation at the point of impact. Figure 3.2 photos show TU-4 before and after the impact test. After the impact test, TU-4 was subjected to a fine and gross leak test as described in Section 3.3. 


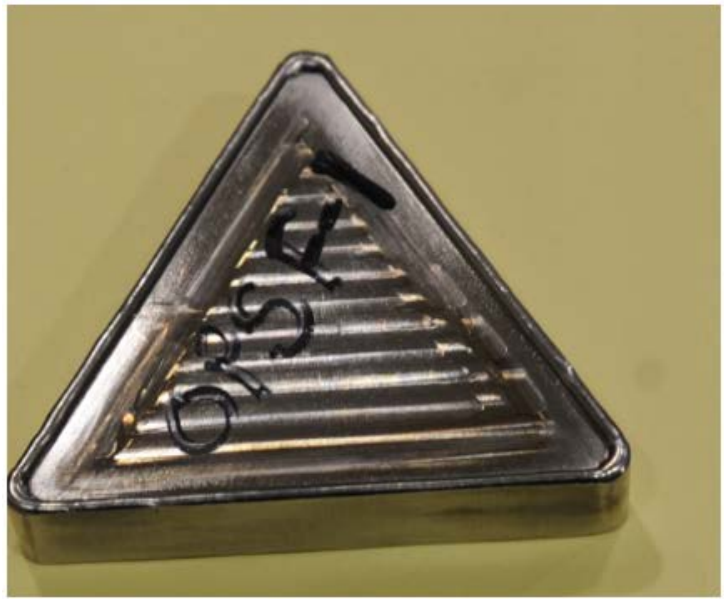

Before Impact

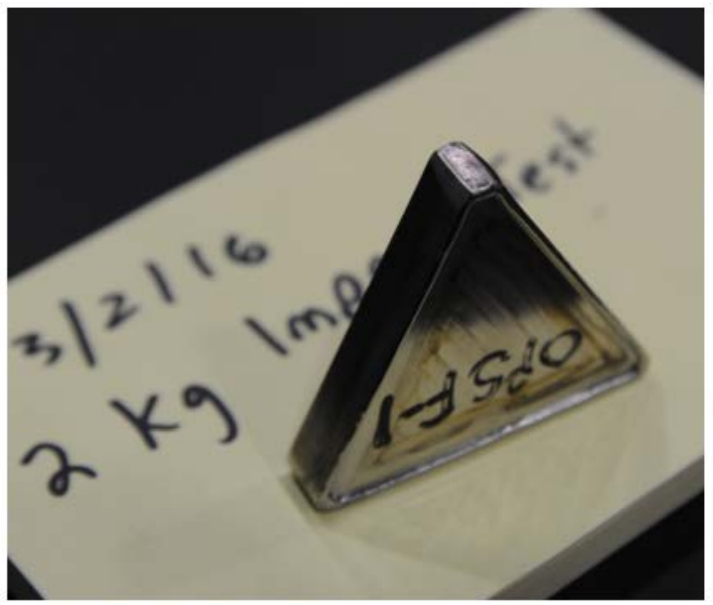

After Impact

Figure 3.2. Before and after impact of the U ZiPCan.

\subsection{HEAT TEST}

The 49 CFR 173.469(b)(4) heat test was performed on the TU-1 (C1-0290) test unit which had been loaded with 3.2 grams of depleted uranium. The special form tile loading log can be found in ORNL Log Book H00034-RSTD Fabrication. The uranium was depleted in the Y-12 National Security Complex (NSC) cauldrons to a high percentage of ${ }^{238} \mathrm{U}$ as batch number D7. The isotopes for the batch D7 uranium can be found in Table 1.1. The test was conducted in the ORNL Radiochemical Engineering Development Center (REDC), Building 7930, Lab 212 Fume Hood (IE-960). The safety aspects of activities for this heat test are controlled by the ORNL Research Hazard Assessment and Control (RHAC) Research Safety Summary (RSS) 919, REDC Bldg. 7930 Development Laboratory Operations. The furnace used was a Thermolyn Model \#F47925, Serial No. 0152853201110405, property number 18334 (Figure 3.). The furnace has a noncalibrated integrated controller. Two 12-inch Type K thermocouple probes (BF3874 and BF3F05) were calibrated before the test and inserted into the top of the furnace and extended into the center of the furnace cavity (Thermocouple 1 - BF3874; Thermocouple 2 - BF3F05 Figure 3.4). The probe was connected to a calibrated fluke thermometer B1332, Serial No. 36370410WS, with a calibration due date of 9/27/2017. 


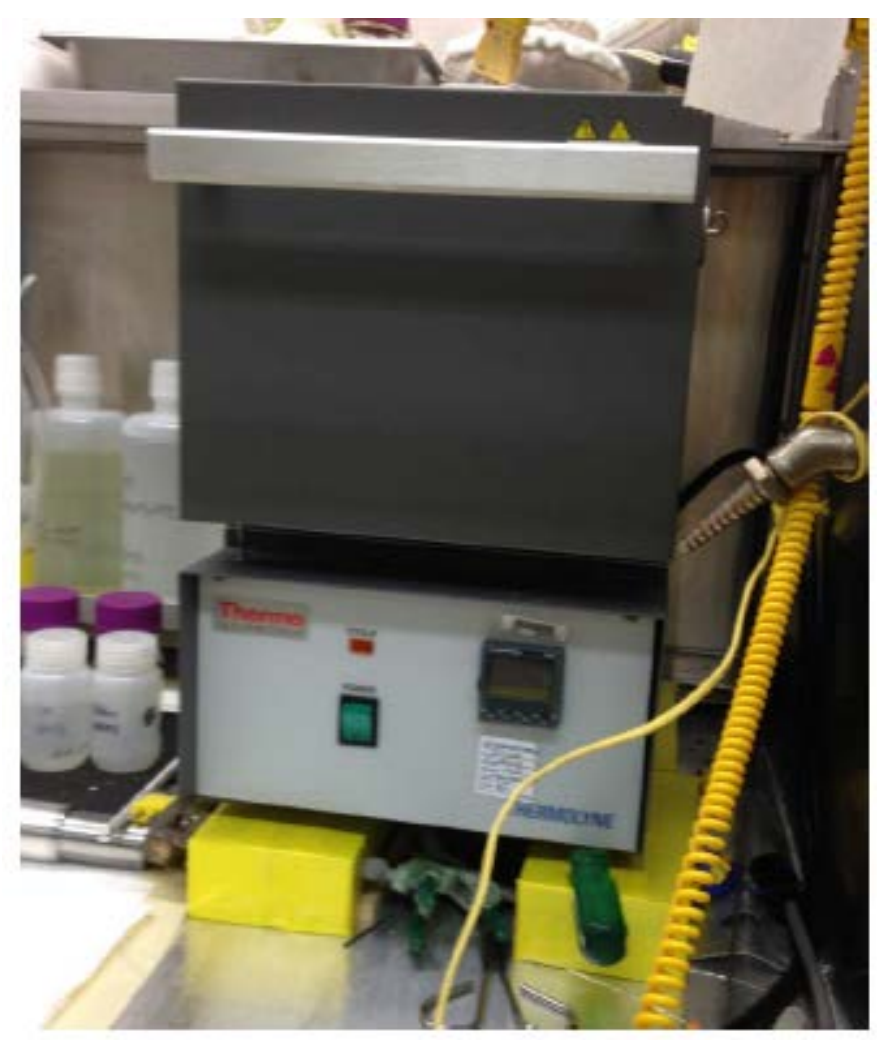

Figure 3.3. Heat test furnace in REDC.

\begin{tabular}{|c|c|c|c|c|c|c|}
\hline \multirow{2}{*}{$\frac{\text { Job\# } 3054371}{\text { Date: } 1 / 24 / 17}$} & & & & & & \multirow{2}{*}{$\begin{array}{l}\text { Tech: } 30220 \\
\text { Std: A001277 }\end{array}$} \\
\hline & & \multicolumn{3}{|c|}{ Technical Support Department } & & \\
\hline & \multicolumn{5}{|c|}{ Instrument Data Continuation Sheet } & M210101 \\
\hline & & & & & & A002021 \\
\hline \multirow[t]{2}{*}{ Furnace } & Standard & \multicolumn{4}{|c|}{ UUT Reading } & \\
\hline & Type S & BF3874 & Error & BF3F05 & Error & \\
\hline 21.5 & 21.5 & 20.9 & -0.6 & 21.1 & -0.4 & \\
\hline 750.0 & 754.1 & 755.0 & 0.9 & 754 & -0.1 & \\
\hline 800.0 & 803.5 & 804.5 & 1.0 & 803.6 & 0.1 & \\
\hline 850.0 & 854.0 & 855.0 & 1.0 & 854.4 & 0.4 & \\
\hline 900.0 & 904.3 & 905.4 & 1.1 & 905.1 & 0.8 & \\
\hline 950.0 & 955.4 & 956.9 & 1.5 & 956.3 & 0.9 & \\
\hline
\end{tabular}

Thermocouple 1 - BF3874; Thermocouple 2 - BF3F05

Figure 3.4. Type $\mathrm{K}$ thermocouple calibration record.

The test was performed according to the procedure outlined in the Test Plan for the Special Form Qualification Testing of the U ZiPCan Triangle Encasement, ORNL/NTRC-074, Section 3.7.2, and testing activities and results were recorded on Test Forms 2, 3, and 4 from the test plan. The furnace was preheated above $800^{\circ} \mathrm{C}$ for three hours. After a three-hour heat soaking period at a constant temperature of $980^{\circ} \mathrm{C}$, the furnace door was opened, and TU-1 was inserted into the furnace cavity. The furnace door was closed, and when both thermocouples had a furnace reading above $800^{\circ} \mathrm{C}$, the 10 -minute thermal test was started (Figure 3.5). Thermocouple 1 is BF3874, and thermocouple 2 is BF3F05. A noncalibrated 
stop watch was used to record the temperatures from both thermocouples every 30 seconds for 10 minutes. After the 10-minute period, the door was opened, and TU-1 was removed from the furnace and allowed to cool naturally. The thermal test resulted in an out-of-plane bulge (pillow effect) of the test unit, which is shown in Figure 3.6. There was a discoloration on the outer surface of the test unit. The test unit was helium leak tested and bubble tested after the thermal test.

\section{U ZipCan Thermal Test (C1-0290)}
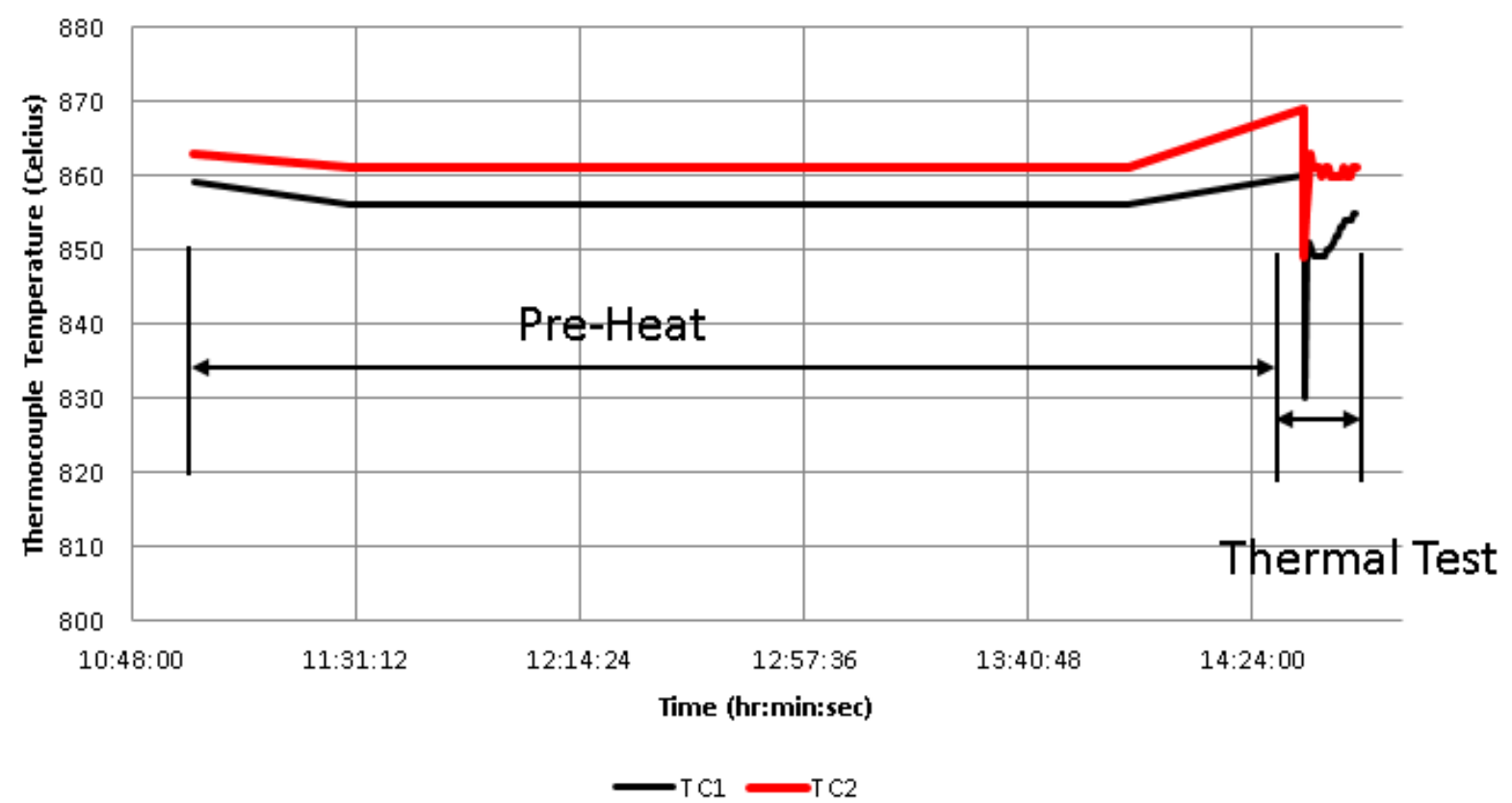

Figure 3.5. Heat test temperature profile.
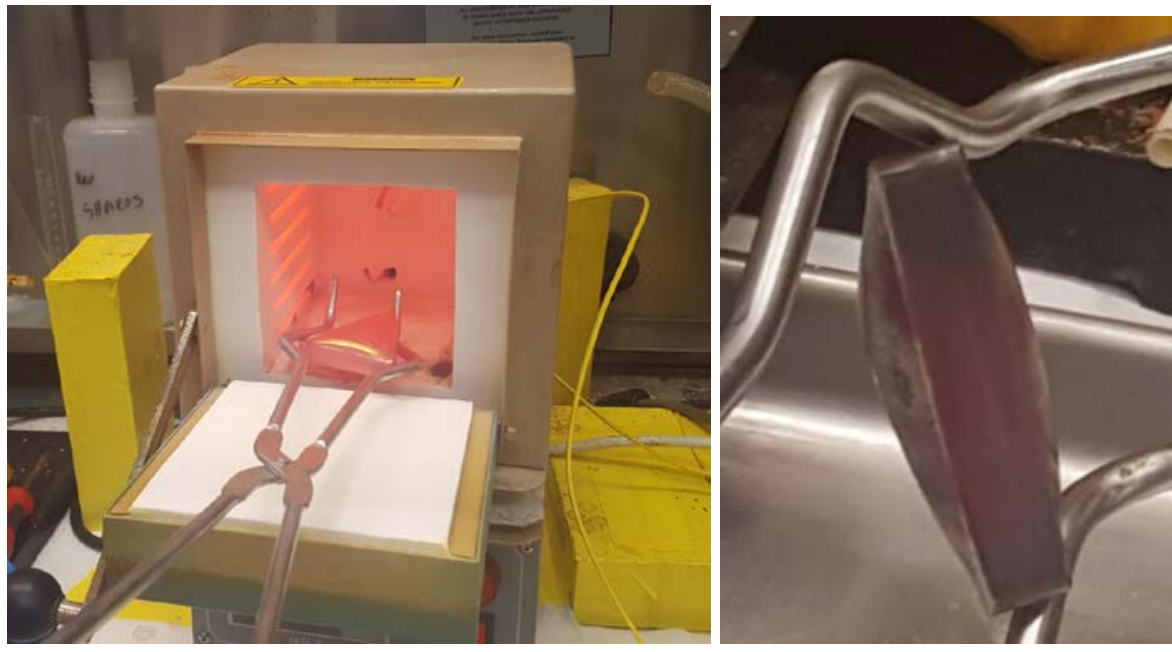

Figure 3.6. U ZipCan post heat test results. 


\subsection{LEAK RATE TESTING}

\subsubsection{Evacuated Envelope (with Back Pressurization)}

Leak rate tests that met the test requirements of (49 CFR 173.469 (a)(4)(i)) were performed individually on each test unit before after each special form test. The leak rate tests were performed using ANSI N14.5-2014 American National Standard for Radioactive Materials - Leakage Tests on Packages for Shipment, Table A.1, Test Description A.5.5, Evacuated Envelope (with back pressurization) and Test Description A.5.6 Gas bubble techniques. The American National Standards Institute (ANSI) document indicates that the back-pressure method ". . . is ideal for welded capsules from very small sizes up to the sizes limited by the dimensions of the pressurizing chamber," and that the "nominal test sensitivity $=10^{-3}-10^{-8} \mathrm{ref}-\mathrm{cm} / \mathrm{s}$ " and the bubble test method are used for hermetically sealed test specimens.

Section A.5.5 of ANSI N14.5-1997, Evacuated Envelope with Helium Back Pressure of the ANSI document references ASTM E 493, Standard Test Methods for Leaks Using the Mass Spectrometer Leak Detector in the Inside-Out Testing Mode. This American Society for Testing and Materials (ASTM) standard provides the method for converting a measured leak rate using the evacuated envelope with the helium back-pressure method into the standardized leak rate that must be compared to the pass/fail criteria specified in 49 CFR 173.469(a)(4)(i), which is $10^{-4}$ torr- $1 / \mathrm{s}\left(1.3 \times 10^{-4} \mathrm{~atm}-\mathrm{cm}^{3} / \mathrm{s}\right)$.

The equation provided in Section 11.1.9 of ASTM E493 is:

$$
\mathrm{S}_{1}=\left(\mathrm{P}_{\mathrm{e}} / \mathrm{P}_{\mathrm{a}}\right) \times\left(1-\mathrm{e}^{(-3600 * \mathrm{a} * \mathrm{~T})}\right) *\left(\mathrm{e}^{(-\mathrm{a} * \mathrm{t})}\right) \times \mathrm{L}
$$

where:

$$
\begin{aligned}
& \mathrm{S}_{1}=\text { indicated (measured) leak rate }(\mathrm{cc} / \mathrm{s}) \\
& \mathrm{P}_{\mathrm{e}}=\text { bombing pressure of helium (absolute) } \\
& \mathrm{P}_{\mathrm{a}}=\text { atmospheric pressure (absolute) } \\
& \mathrm{T}=\text { bombing time (hours) } \\
& \mathrm{t}=\text { waiting time between bombing and testing }(\mathrm{s}) \\
& \mathrm{L}=\text { actual (standardized) leak rate }(\mathrm{atm}-\mathrm{cc} / \mathrm{s}) \\
& \mathrm{a}=\mathrm{L} / \mathrm{V} \text { where } \mathrm{V}=\text { internal volume } \\
& \mathrm{e}=2.71 \text { (natural logarithm). }
\end{aligned}
$$

Since $\mathrm{S}_{1}$ is being measured and the objective is to solve for $\mathrm{L}$, an iterative solver is required to find the solution. The equation was solved using MS Excel. Note that the ASTM standard uses the term bombing, while the ANSI standard uses the term back-pressure. These terms are synonymous and are used interchangeably in this report.

To solve Equation 1, the internal volume (i.e., void space) within the test units must be known. For the test units, this internal volume consisted of accessible internal void spaces. Based on the dimensions provided by the drawings, along with queried information from the computer aided design software used to create the drawings (to determine the volume of the irregularly shaped Part \#2 shown in Figure 1.1), the void volume is $0.6 \mathrm{cc}$.

Test units TU-1 (C1-0290) and TU-4 (OPSF1) were leak tested at ORNL by certified ASNT Level II and Level III NDT leak testing personnel using the NDE-70 R.6 procedure. See Appendixes D and E for leak tester certification and the leak testing procedure. The test units were leak tested before and after each special form test. The test apparatuses used for these tests employed a spectrometer tuned to detect helium, a calibrated helium leak to calibrate the system, and two separate vessels — one for helium back 
pressurization, and a second one for the subsequent helium leakage rate testing under vacuum conditions. Figure 3.7 provides a schematic of the system used for helium back pressurization, and Figure 3.8 shows a schematic of the system used for the helium leakage rate test. Leak rate test variables and results for TU-1 and TU-4 are shown in Table 3.1.

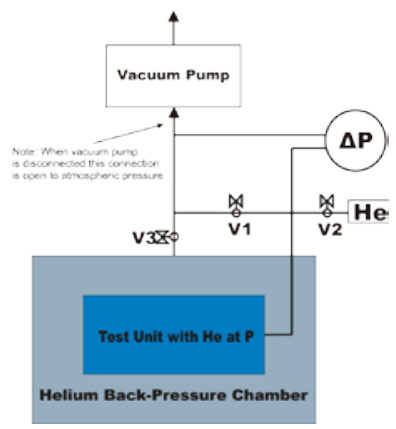

Figure 3.7. Diagram of helium back pressurization test.

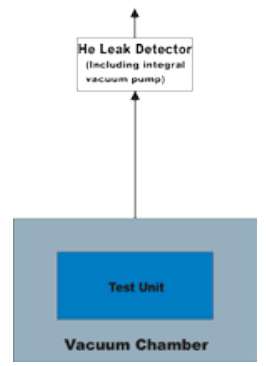

Figure 3.8. Diagram of helium leak testing system.

\subsubsection{Gas bubble techniques}

The gas bubble test was performed using the methods described in ANSI N14.5-2014, American National Standard for Radioactive Materials - Leakage Tests on Packages for Shipment, Table A.1, Test Description A.5.6 (b), Vacuum Bubble. The method involves immersing the test unit in a liquid and then producing a vacuum above the liquid (e.g., water/glycol or isopropyl alcohol) in which the test item is submerged. A leak is indicated by a stream of bubbles (). This method applies to welded capsules. The nominal test sensitivity is $10^{-3} \mathrm{ref}-\mathrm{cm}^{3} / \mathrm{s}\left(10^{-4} \mathrm{~Pa}-\mathrm{m}^{3} / \mathrm{s}\right)$. Test units TU-1 (C1-0290) and TU-4 (OPSF1) were bubble tested. Table 3.2 shows the results for each of the tests. See Appendixes D and E for leak tester certification and the leak testing procedure. 


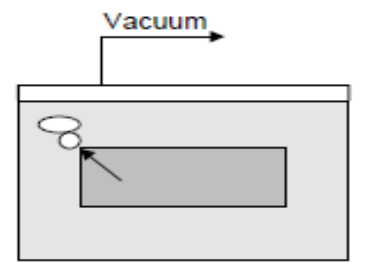

Figure 3.9. Vacuum bubble test.

Table 3.1. Leak rate test variables and results for TU-1 and TU-4

\begin{tabular}{|c|c|c|c|c|}
\hline \multirow{3}{*}{ Parameter } & \multicolumn{4}{|c|}{ Test unit } \\
\hline & \multicolumn{2}{|c|}{ TU-4 (OPSF1) } & \multicolumn{2}{|c|}{ TU-1 (C1-0290) } \\
\hline & Leak test 1 & Leak test 2 & Leak test 1 & Leak test 2 \\
\hline Void space - V (cc) & 1.057 & 1.057 & 1.057 & 2.2 \\
\hline Bombing pressure $-P_{e}$ (psig) & 30.0 & 50.0 & 30 & 30.0 \\
\hline Atmospheric pressure $-P_{a}$ (psia) & 14.69 & 14.69 & 14.69 & 14.69 \\
\hline Bombing time - T (hr) & 0.5 & 1 & 0.5 & 0.5 \\
\hline Time between bombing and testing $-t(s)$ & $<3,600$ & $<1,800$ & 3,600 & 3,600 \\
\hline $\begin{array}{l}\text { Measured leak rate (cc/s) - } \mathrm{S}_{l}(\mathrm{~atm}-\mathrm{cc} \\
\mathrm{He} / \mathrm{s})\end{array}$ & $2.0 \times 10^{-7}$ & $5.0 \times 10^{-9}$ & $1.7 \times 10^{-7}$ & $7.6 \times 10^{-7}$ \\
\hline $\mathbf{a}=\mathbf{L} / \mathbf{V}\left(\mathbf{s}^{-1}\right)$ & $<9.46 \times 10^{-5}$ & $<9.46 \times 10^{-8}$ & $<9.46 \times 10^{-5}$ & $<9.46 \times 10^{-5}$ \\
\hline Standardized leak rate - L (atm-cc He/s) & $<1.0 \times 10^{-4}$ & $<1.0 \times 10^{-7}$ & $<1.0 \times 10^{-4}$ & $<1.0 \times 10^{-4}$ \\
\hline
\end{tabular}

Table 3.2. Bubble test results for TU-1 and TU-4

\begin{tabular}{|c|c|c|c|c|}
\hline \multirow{3}{*}{ Parameter } & \multicolumn{4}{|c|}{ Test unit } \\
\hline & \multicolumn{2}{|c|}{ TU-1 (C1-0290) } & \multicolumn{2}{|c|}{ TU-4 (OPSF1) } \\
\hline & Bubble test 1 & Bubble test 2 & Bubble test 1 & Bubble Test 2 \\
\hline $\begin{array}{l}\text { Bubble test } \\
\text { pass/ fail }\end{array}$ & pass & pass & pass & pass \\
\hline
\end{tabular}




\section{CONCLUSION}

Two prototype U ZiPCans were subjected to the tests specified in 49 CFR 173.469 and 10 CFR 71.75 (d)(1)(i), ISO 2919:1999(E), Class 4 impact test. One unit was subjected to the impact test and to pre- and post-leak rate tests, the other unit was subjected to the heat test followed by a leak rate test. Each unit easily surpassed the leak rate criteria following each test, each test specimen did not break or shatter when subjected to the impact test, and the specimen did not melt or disperse when subjected to the heat test.

This testing process has shown that the design of the U Zirconia Pre-Encapsulated Canister meets Special Form Criteria. 


\section{APPENDIX A. U ZIPCAN DRAWINGS}




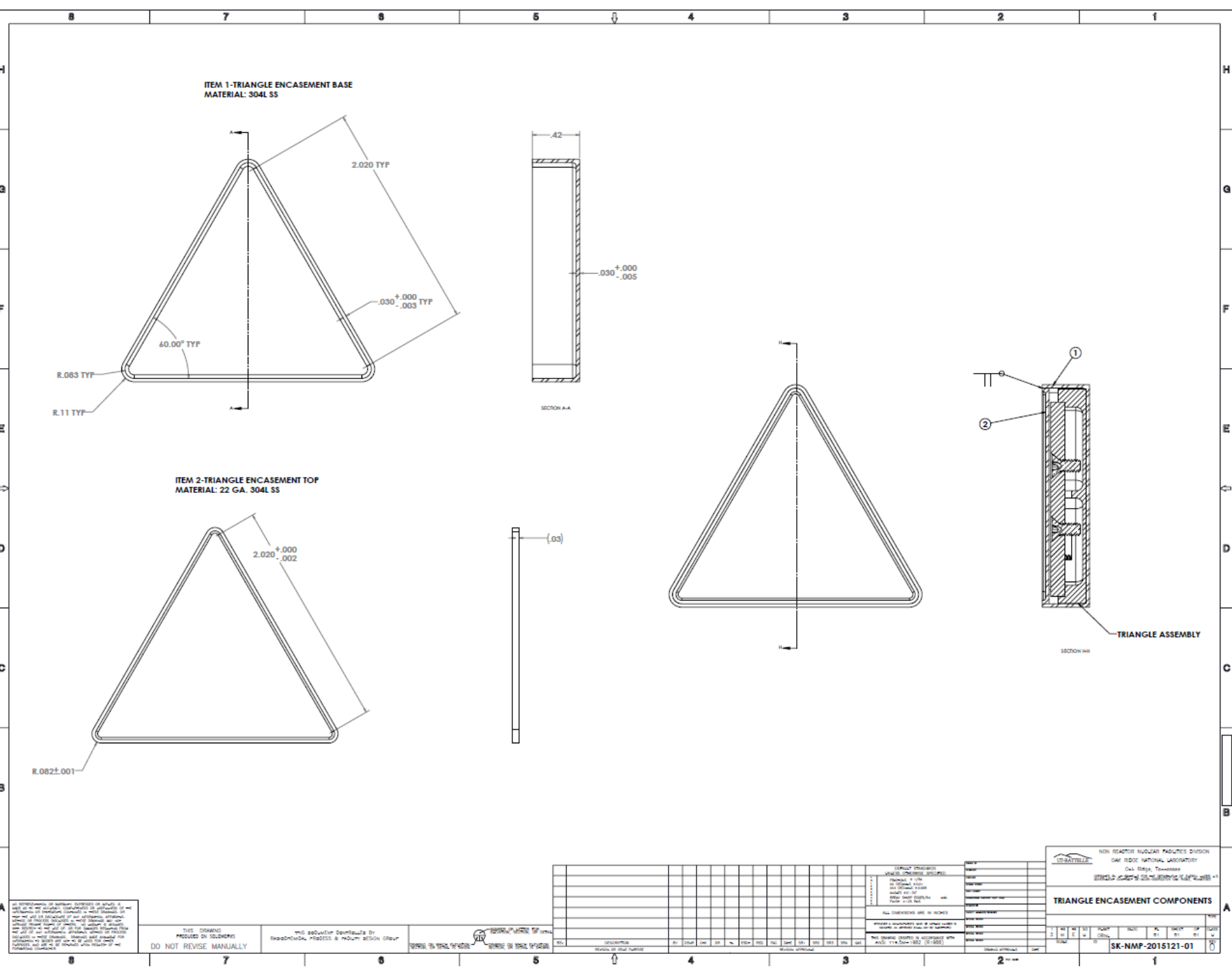

Figure A.1. U ZiPCan engineering drawing. 


\section{APPENDIX B. TEST FORMS}




\section{LEAK TEST REPORT}

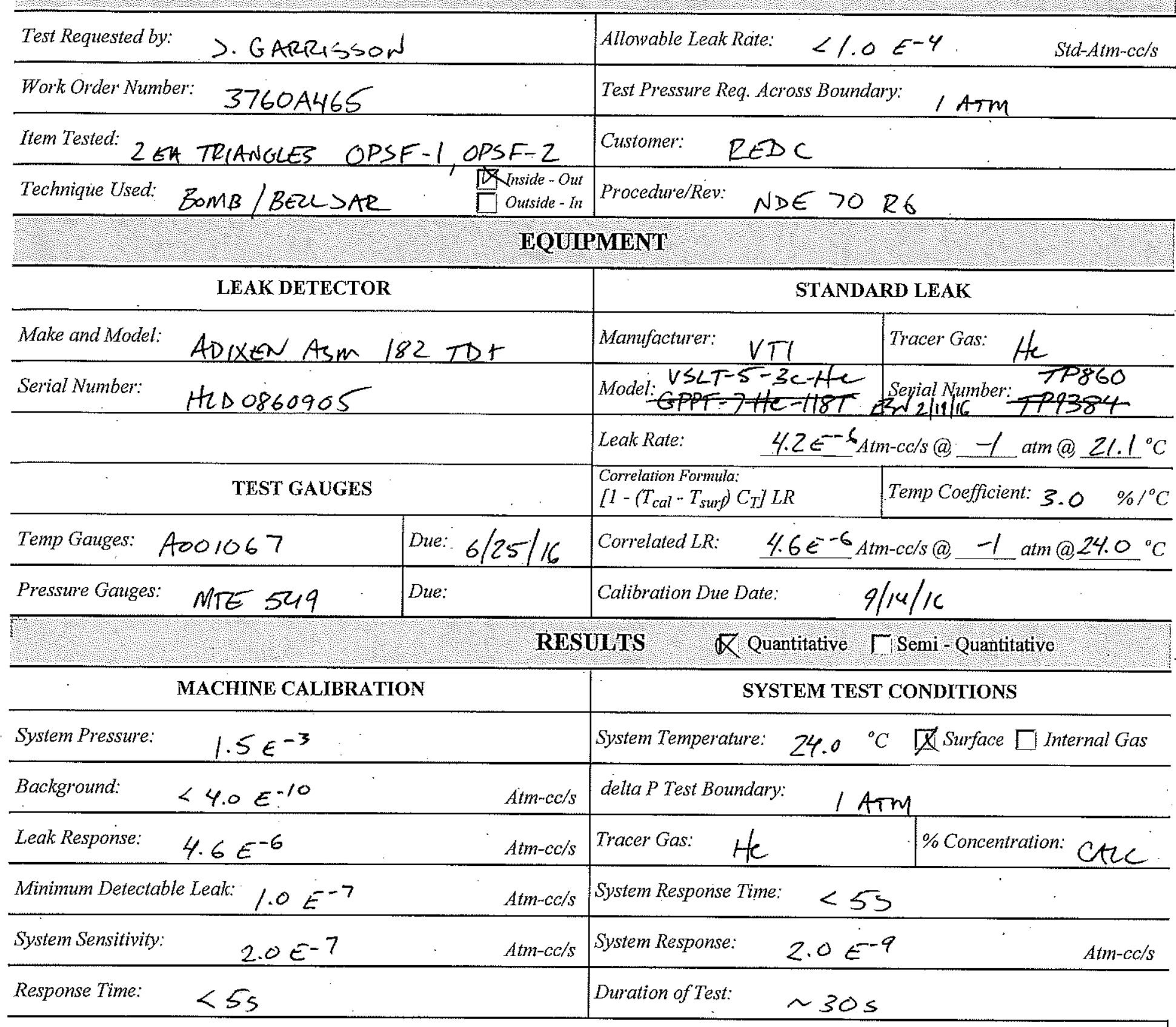

Aux. Equipment:

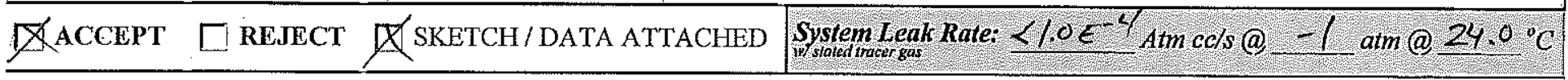
COMMENTS:

Pre impaut - Oscarm.

Test Conducted By: (Print \& Sign Name/Level):

E.VIOAL
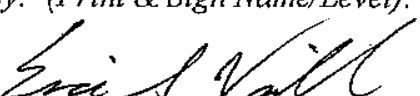

Date:

$2 / 19 / 16$

Time: 


\section{BOMBING TEST REPORT (Supplement)}

\begin{tabular}{|l|l}
\hline Leak Test Report Number: $\quad 2 / 19 / 16-2$ & Allowable Leak Rate: $\quad<1.0 e^{-4}$
\end{tabular}

Item(s) Tested:

$$
\text { OPSF-1, OPSF-2 }
$$

\section{TRACER GAS BOMBING AND LEAK TEST}

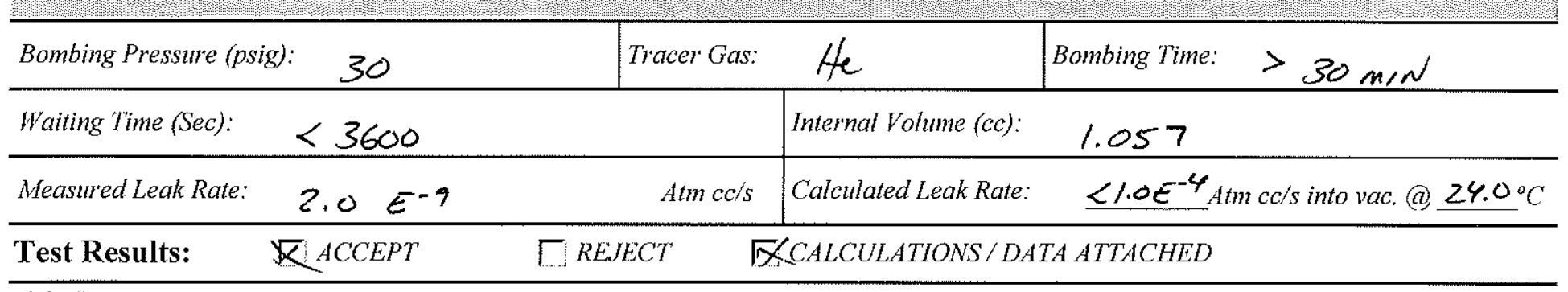

COMMENTS: 


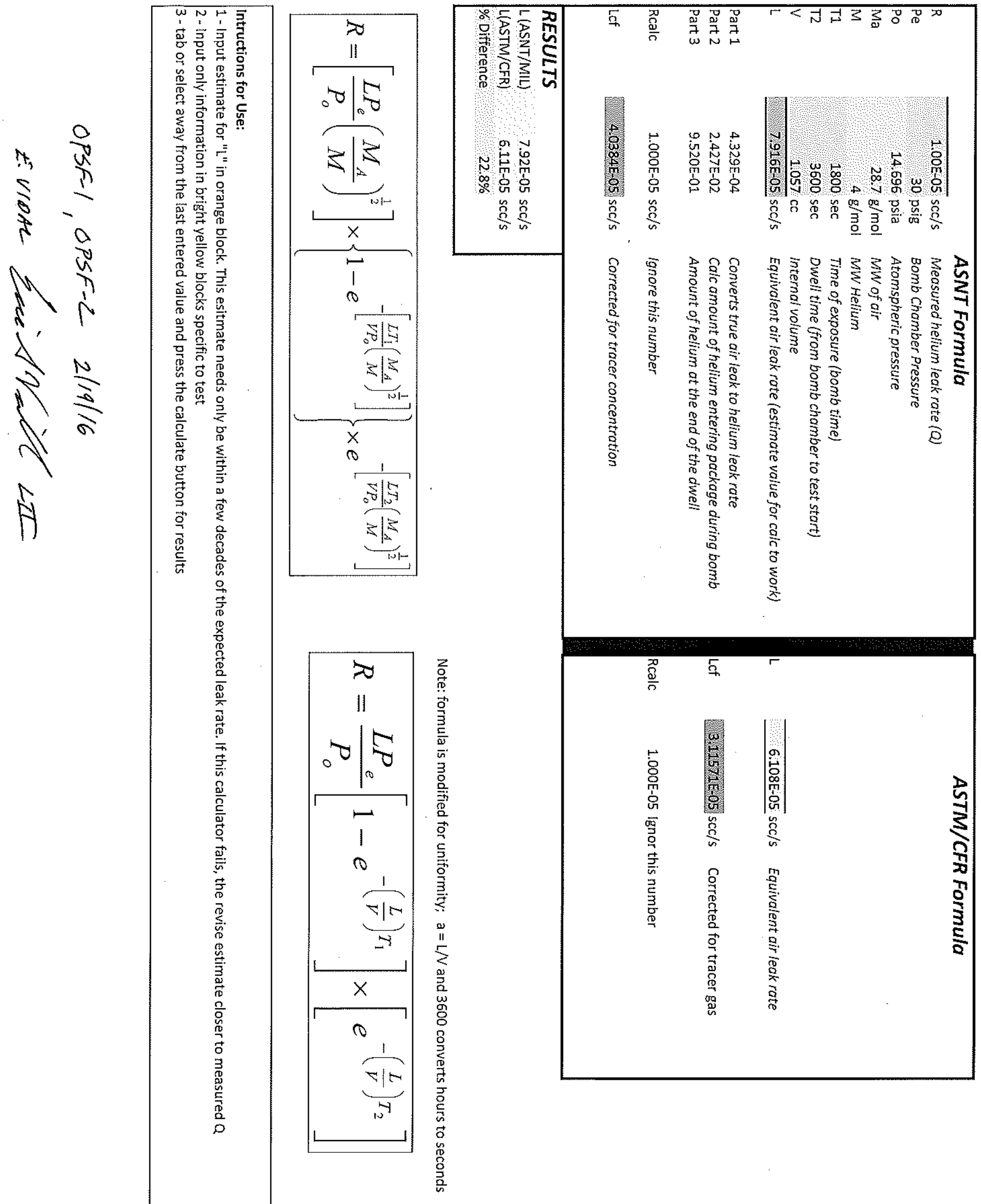




\section{LEAK TEST REPORT - BUBBIE TEST}

\begin{tabular}{|c|c|}
\hline Test Requested by: $>$.GARRISON & Customer: \\
\hline Work Order Number: $\quad 3760 A 465$ & Procedure: NDE 70R6 \\
\hline Item Tested: 2 EA. TRIANGLES OPSF-1, OPSF-2 & Test Pressure Required: $\quad 15 \mathrm{in} / \mathrm{g}$ \\
\hline Technique Used: Vae Box & Liquid Media Used: IMmERSIT CIM 150 \\
\hline Test Gas Used: & Liquid Applicator Type: IMMERSION \\
\hline Inspection Light Intensity: $>>100 \mathrm{FC}$ & Post Cleaning Method: DEMIN HzO Rinse \\
\hline
\end{tabular}

Direct Pressure Technique $\square \quad$ Vacuum Pressure Technique A

Component Limits of Test:

\begin{tabular}{|l|l|}
\hline Component Test Site BLDG $\$ 500$ & Component Installation Site \\
\hline
\end{tabular}

\begin{tabular}{|c|c|c|c|c|c|c|c|}
\hline \multicolumn{4}{|c|}{ Gauges } & \multicolumn{2}{|c|}{ Test Pressure } & \multicolumn{2}{|c|}{ Temperature } \\
\hline Mfg & IDNo & $\begin{array}{c}\text { Calibration } \\
\text { Date }\end{array}$ & Range & Beginning & End & Beginning & End \\
\hline & $A 002126$ & $8 / 26 / 15$ & $0-30 \mathrm{~m} \mathrm{Hg}$ & 15 in thg & 15 inttg & AMBBIENT & AMBIOUT \\
\hline
\end{tabular}

Temperature Measuring Device

\begin{tabular}{|l|l|l|l|}
\hline Mfg. & Model - & Range - & I.D. Number - \\
\hline
\end{tabular}

\begin{tabular}{lll}
\hline RESULTS & $\mathrm{X}$ ACGEPT \\
\hline
\end{tabular}

\begin{tabular}{|c|c|c|}
\hline Comments: & AMBIENT SHOP ATR $\sim 70^{\circ} \mathrm{F}$ & \\
\hline $\begin{array}{l}\text { Test Conducted By } \\
\text { EVIDAC }\end{array}$ & (Print \& Sign Name/Level): & Date: $2 / 22 / 16$ \\
\hline
\end{tabular}


TEST FORM 1 - Impact Test ISO 2919

Test Unit OPSF-

VERIFIED

$\checkmark$

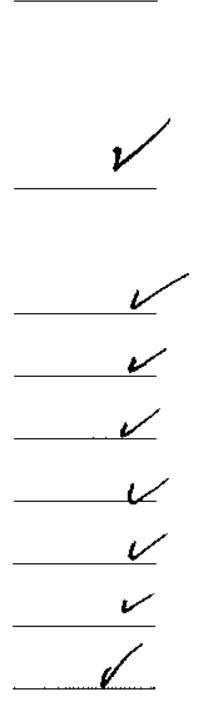

TASK

The weight of the impact billet has been measured and verified to be $2 \mathrm{~kg}$ or greater:

Measured weight of billet

$2.000 \quad(\mathrm{~kg})$

Scale used for measurement: (kg)

Calibration due: Metrology Scale

The calibration of the $1-\mathrm{m}$ ruler has been verified:

1-m Ruler Equipment \#_A Calibration due: $11 / 3 / 16$

The test unit with supporting device has been placed (centered) on NTRC indoor drop pad.

The drop test release mechanism has been attached to the crane.

The impact billet has been captured by the release mechanism.

The billet has been centered over the test unit and a picture has been taken.

The billet has been raised to height of 1 meter over the highest point of the test unit and a picture has been taken.

The billet was released and impacted the test unit.

All observable damage to the test unit caused by the impact test has been recorded and pictures of the test unit after the impact test have been taken.

Comments:
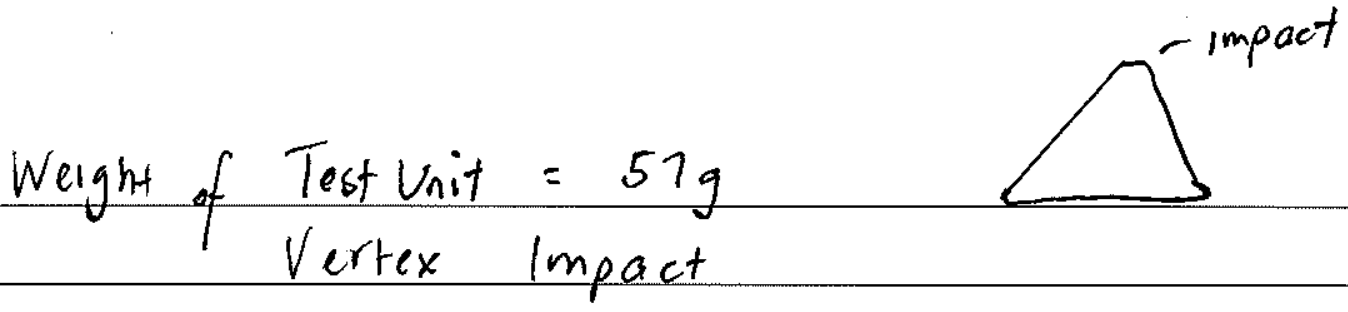

I certify that the above tasks have been performed and that the observations and comments are correct.
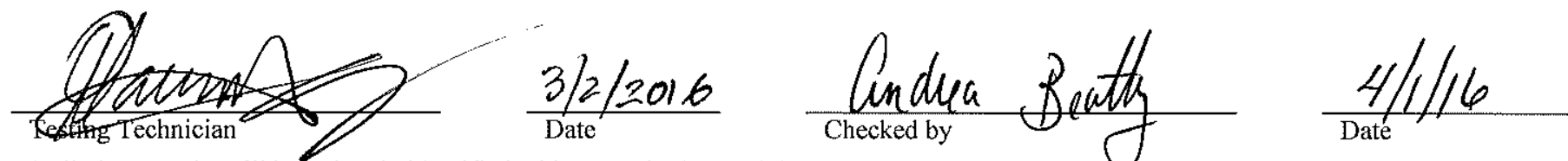

*All photographs will be uniquely identified with test unit, date and time to ensure that the proper sequence can be reconstructed 


\section{LEAK TEST REPORT}

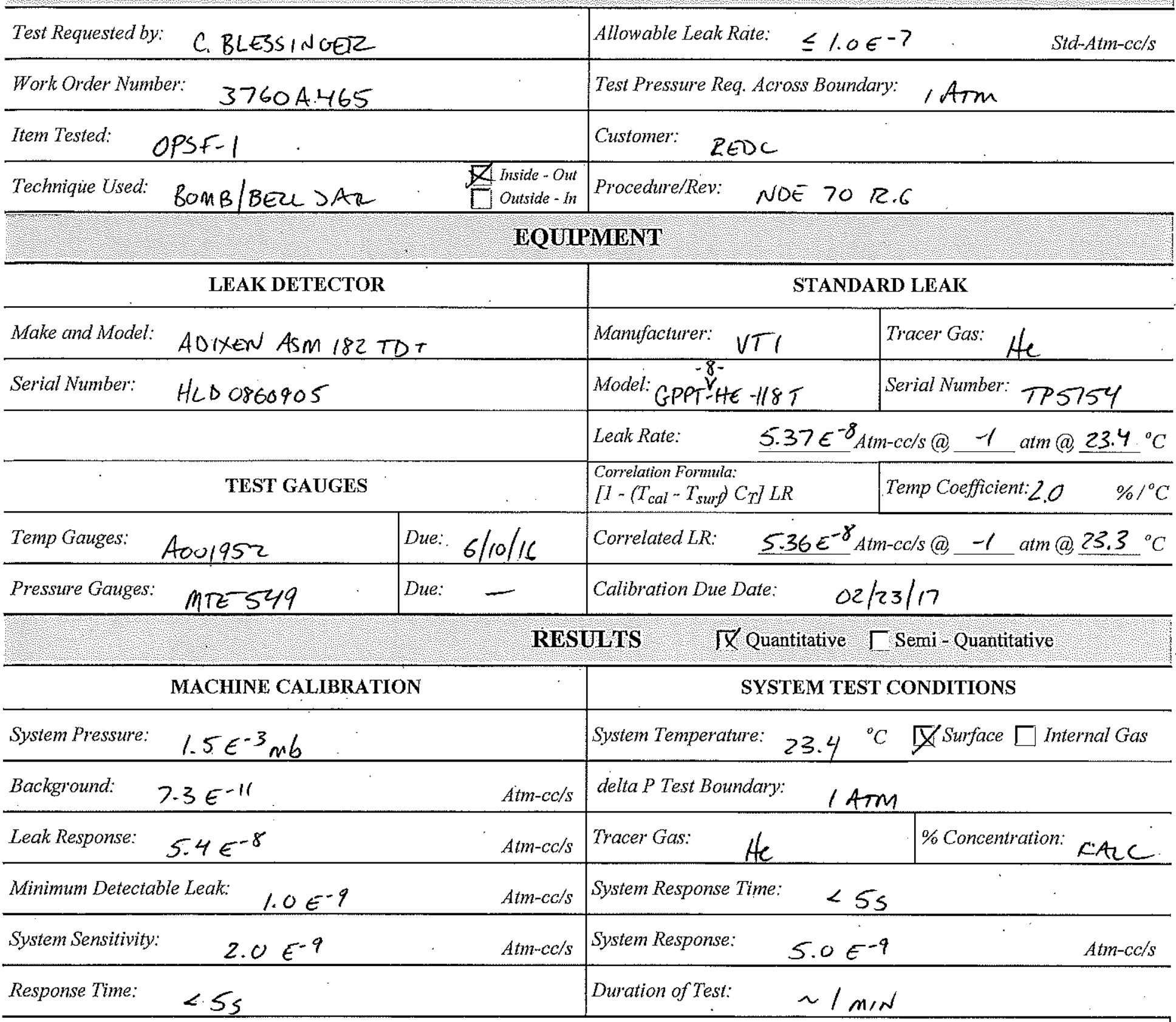

Aux. Equipment:

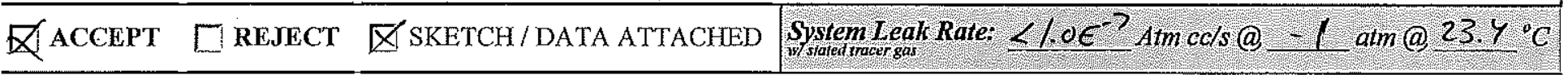
COMMENTS:

$$
\text { FINE } \angle T \text { - POST DROPTEST/IMPACT TEBT }
$$

\begin{tabular}{|c|c|c|}
\hline Test Conducted By: (Print \& Sign Name/Level): & $\begin{array}{l}\text { Date: } \\
\quad 3 / 9 / 16\end{array}$ & Time: $3: 00$ \\
\hline
\end{tabular}


BOMBING TEST REPORT (Supplement)

\begin{tabular}{l|l}
\hline Leak Test Report Number: $\quad 3 / 9 / 16-2$ & Allowable Leak Rate: $\leq 1.0 \in-7$
\end{tabular}

Item(s) Tested:

$$
\text { OPSF-1 }
$$

TRACER GAS BOMBING AND LEAK TEST

\begin{tabular}{|c|c|c|c|c|}
\hline Bombing Pressure (ps & 50 & Tracer Gas: & $H$ & Bombing Time: $>/ H_{R}$ \\
\hline Waiting Time (Sec): & $<1800$ & & Internal Volume (cc): & 1.057 \\
\hline Measured Leak Rate: & $5.0 \epsilon^{-9}$ & Atm $c c / s$ & Calculated Leak Rate: & $\left\langle 1.0 \epsilon^{-7}\right.$ Atm ccls into vac. $@ 23.4{ }^{\circ} \mathrm{C}$ \\
\hline Test Results: & Х $A C C E P T$ & $\Gamma \operatorname{REJECT}$ & \multicolumn{2}{|c|}{$\varnothing C A L C U L A T I O N S / D A T A$ ATTACHED } \\
\hline
\end{tabular}

COMMENTS: 
$\frac{\omega}{D} \frac{0}{n} \frac{0}{n}$

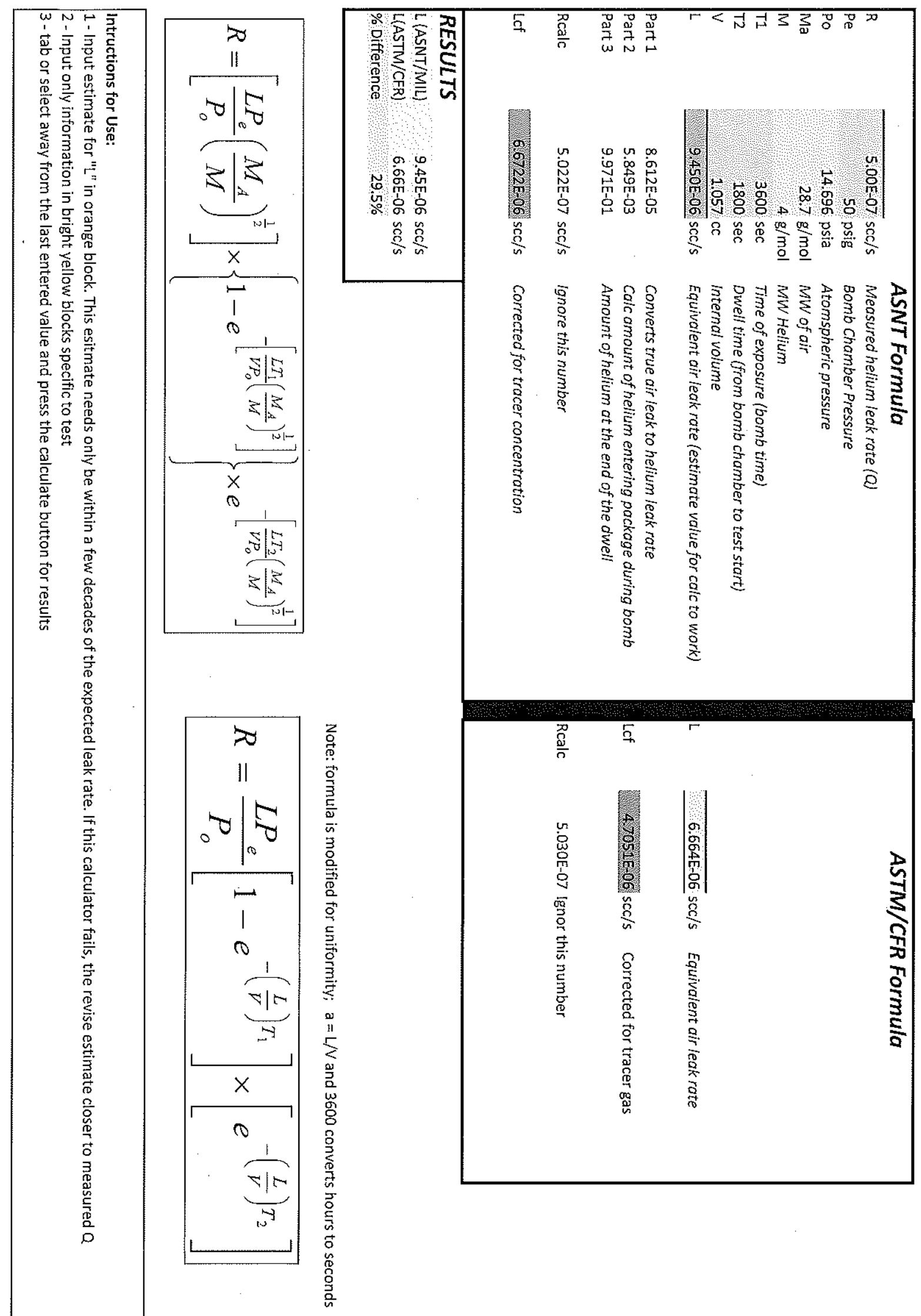


Report Number: $3 / 10 / 16-2$

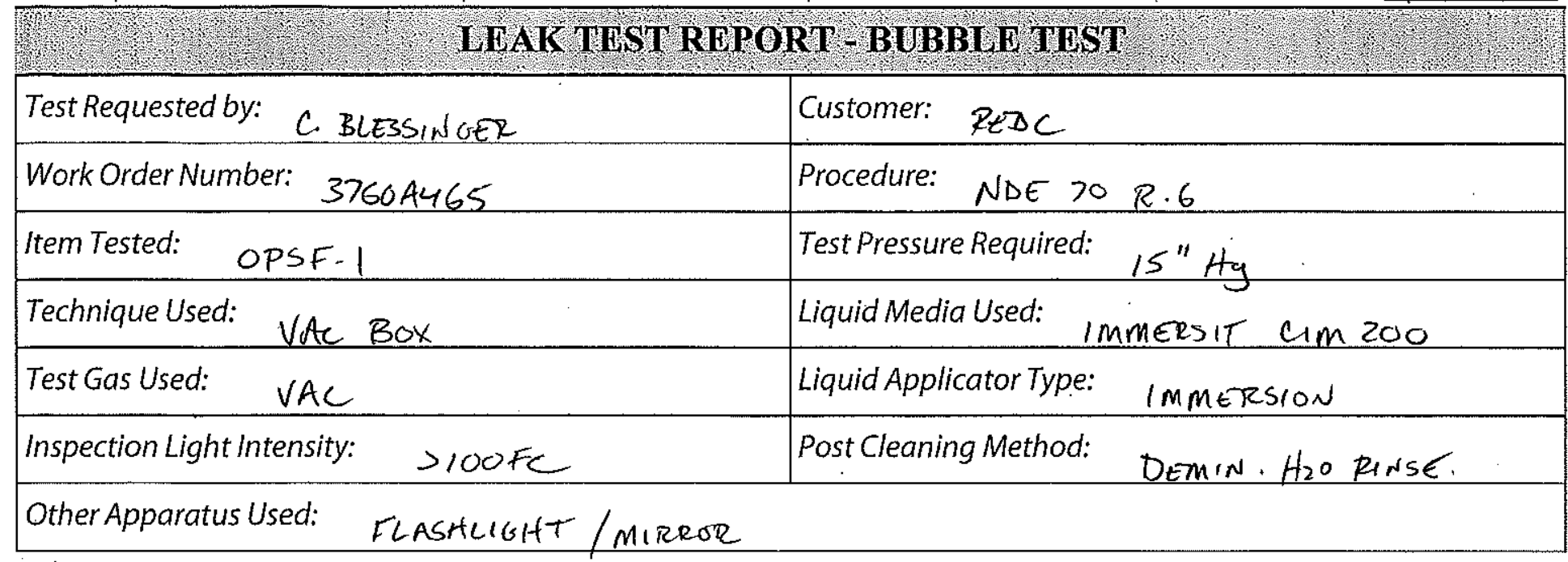

Direct Pressure Technique $\square \quad$ Vacuum Pressure Technique $\triangle$

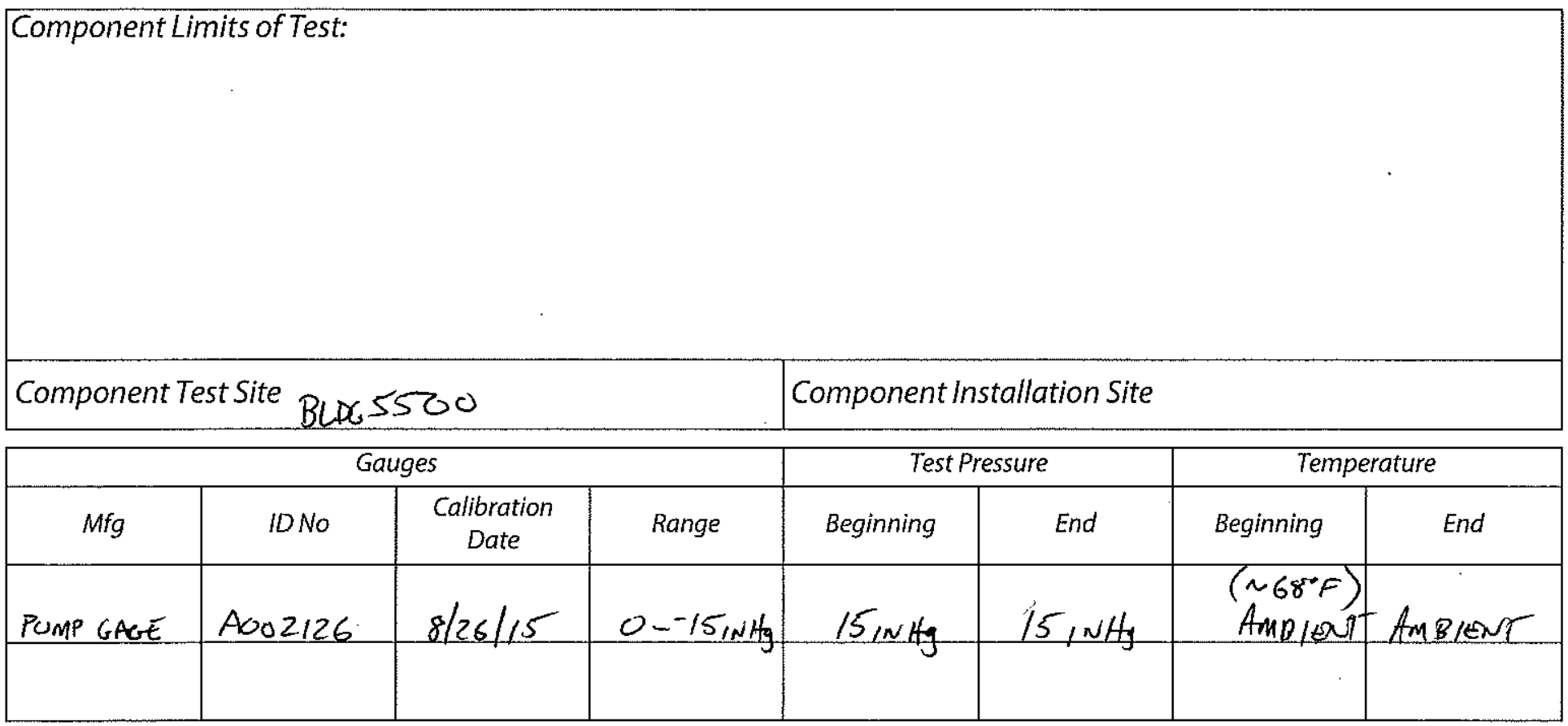

Temperature. Measuring Device

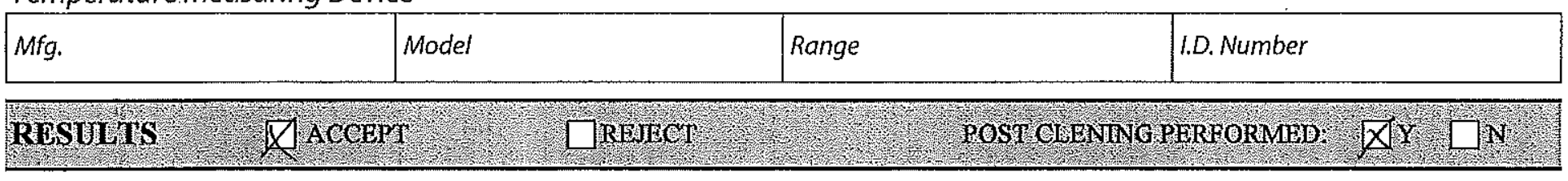

\begin{tabular}{|l|l|}
\hline Comments: \\
\hline Test Conducted By:(Print \& Sign Name/Level): \\
E.VIOAC Date: & $3 / 10 / 16$ \\
\hline
\end{tabular}




\section{LEAK TEST REPORT}

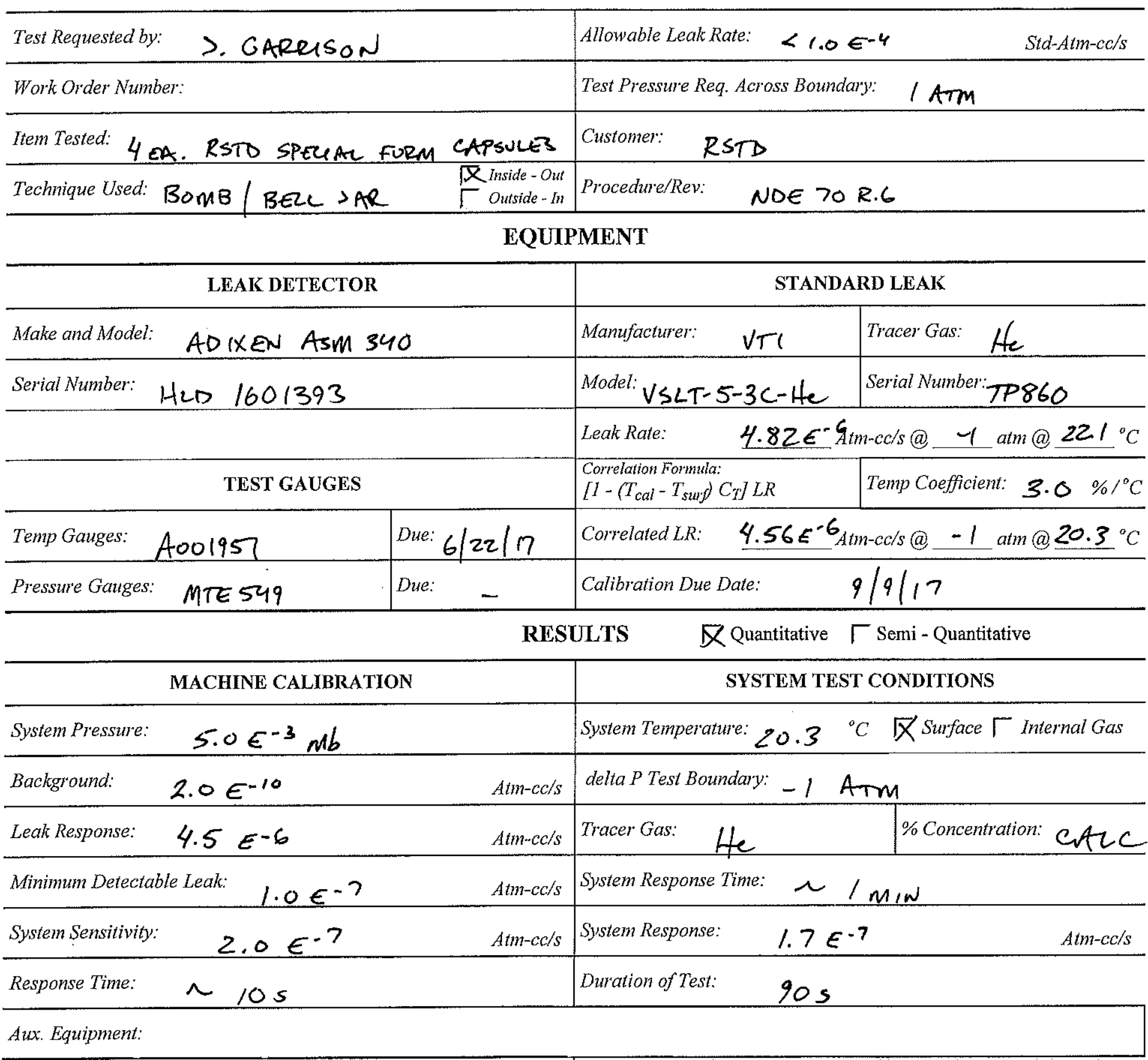

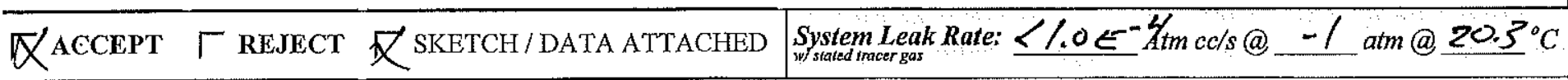
COMMENTS:

$$
\text { SIN: CI-0286, 288, 289,290 FINELT }
$$

Test Conducted By: (Print \& Sign Name/Level):

E.VIDAZ

Date:

$11 / 22 / 16$
Time:

$1: 15$ 


\section{BOMBING TEST REPORT (Supplement)}

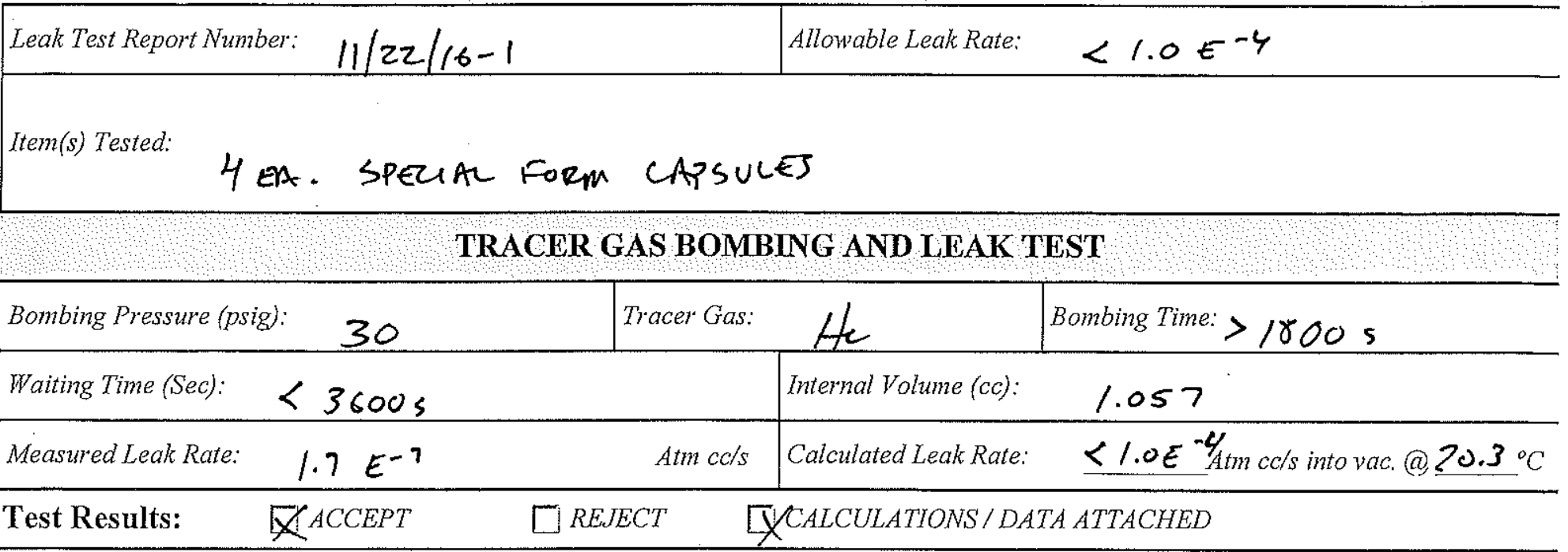

COMMENTS: 


\section{LEAK TEST REPORT - BUBBLE TEST}

\begin{tabular}{|c|c|}
\hline Test Requested by: S. GARRSON & Customer: RSTD \\
\hline Work Order Number: & Procedure: NDE >OR.6 \\
\hline Item Tested: 4 EA. SPEUAC Form CAPSULES & Test Pressure Required: $\quad-15^{\prime \prime} \mathrm{Hy}$ \\
\hline Technique Used: Vote Box & Liquid Media Used: IMMGRSIT cim 200 e $20 \%$ So \\
\hline Test Gas Used: VAL & Liquid Applicator Type: Immersion \\
\hline Inspection Light Intensity: $\quad>100 \mathrm{FC}$ & Post Cleaning Method: RINSE / WIPE \\
\hline OtherApparatus Used: FuAstuoth & \\
\hline
\end{tabular}

Direct Pressure Technique $\square$ Vacum Pressure Technique $\mathbb{A}$

Component Limits of Test:

Component Test Site . 7606 A Component Installation Site

\begin{tabular}{|c|c|c|c|c|c|c|c|}
\hline \multicolumn{4}{|c|}{ Gauges } & \multicolumn{2}{c|}{ Test Pressure } & \multicolumn{2}{c|}{ Temperature } \\
\hline Mfg & 10 No & $\begin{array}{c}\text { Calibration } \\
\text { Date }\end{array}$ & Range & Beginning & End & Beginning & End \\
\hline GAST & A002124 & $8 / 11 / 16$ & $0.30, \mathrm{NH}_{\mathrm{H}}$ & $-15 \mathrm{~N} / \mathrm{Hg}$ & $-15 \mathrm{~N} / \mathrm{tg}$ & $20.3^{\circ} \mathrm{C}$ & $20.3^{\circ} \mathrm{C}$ \\
\hline & & & & & & & \\
\hline
\end{tabular}

Temperature Measuring Device

\begin{tabular}{|l|l|l|l|}
\hline Mfg. OMEGA & Model HH804 & Range K-TYPE & I.D.Number AoO195I \\
\hline
\end{tabular}

\begin{tabular}{|c|c|c|c|}
\hline RESUITS & 义 ACСEPT & $\square$ RERECT & POST CLENING PERTORMED: $Z Y Y, \square N$ \\
\hline
\end{tabular}

Comments:

$$
C_{1}-0286,288,289,290
$$

Test Conducted By: (Print \& Sign Name/Level): 
VERIFIED

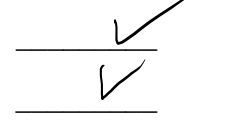

V

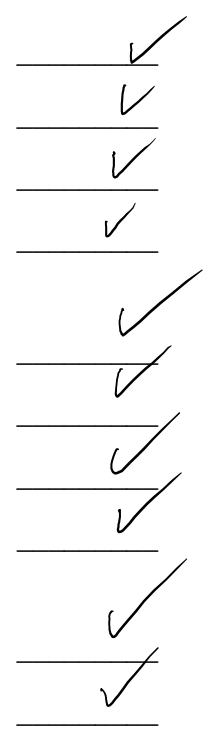

Comments:

\section{TASK}

The test unit tray has been placed in the furnace.

Two calibrated Type $\mathrm{K}$ thermocouples have been installed in the working area of the furnace and attached to the Fluke thermocouple reader.

Fluke Equipment \# B 1332 Calibration Due: $9 / 27 / 2017$

The furnace doors has been closed and the furnace has been turned on with a set point of $850^{\circ} \mathrm{C}$.

Furnace Equipment \# 18334 Calibration Due: No Cal record

Thermocouple readings have been made every 30 minutes for at least 3 hours.

Any changes in the furnace set point during the three-hour preheat period have been recorded on TEST FORM 5.

Just prior to test unit insertion, a final preheat temperature recording was made.

The furnace door has been opened, the test unit inserted, the furnace door closed and the furnace activated with a set point of $850^{\circ} \mathrm{C}\left(1560^{\circ} \mathrm{F}\right)$ (or as adjusted during the preheat process).

When both thermocouple readings have reached $800^{\circ} \mathrm{C}\left(1475^{\circ} \mathrm{F}\right)$, the 10-minute thermal test was started.

Thermocouple readings were taken every 30 seconds for the duration of the 10-minute thermal test.

Adjustments were made to the furnace set point as directed by the test director.

When the 10-minute test period was finished, the furnace was turned off and furnace door was opened to the maximum extent possible.

As soon as conditions permitted, the test unit was removed from the furnace and allowed to cool naturally.

Any deformation or other unusual circumstances regarding the test or the test unit was recorded.

$\begin{array}{ll}\mathrm{C} 1-0290 & \text { Furnace Hood IE } 960 \\ \text { Set }-850^{\circ} \mathrm{C} & T C 2-861^{\circ} \mathrm{C} \quad \text { TC's and Fluke are } \\ T C 1-856^{\circ} \mathrm{C} & \text { calibrated }\end{array}$

I certify that the above tasks have been performed and that the observations and comments are correct.

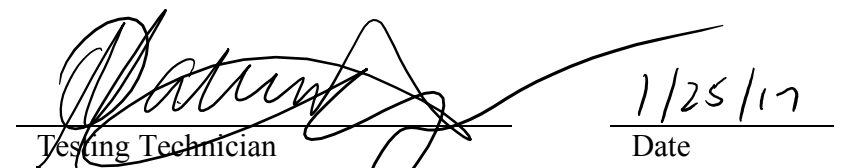

Matthew R Feldman

Checked by
$8 / 18 / 2017$

Date

*All photographs will be anjquely identified with test unit, date and time to ensure that the proper sequence can be reconstructed 
TEST FORM 3 - Thermal Test Preheat Data Sheet

VERIFIED

Record the temperature in the furnace every thirty (30) minutes for the duration of the preheat (at least 3 hours):

\begin{tabular}{|c|c|c|}
\hline Time & Thermocouple $\left.1{ }^{\circ} \mathrm{C}\right)$ & Thermocouple $2{ }^{\circ} \mathrm{C}$ \\
\hline $11: 00$ & 859 & 863 \\
\hline $11: 30$ & 856 & 861 \\
\hline $12: 00$ & 856 & 861 \\
\hline $12: 30$ & 856 & 861 \\
\hline $1: 00$ & 856 & 861 \\
\hline $1: 30$ & 856 & 861 \\
\hline $2: 00$ & 856 & 861 \\
\hline & & \\
\hline & & \\
\hline & & \\
\hline & & \\
\hline
\end{tabular}

TASK
Test Plan ORNL/NTRC-074

$\underline{\text { Rev. } 0}$

Test Unit L - C1-0290

comments: Three hour pe heal- above $850^{\circ} \mathrm{C}$

thermocouple 1= BF 3874

Thermocouple $2=B F 3 F 05$

I certify the the the he have been performed and that the observations and comments are correct.

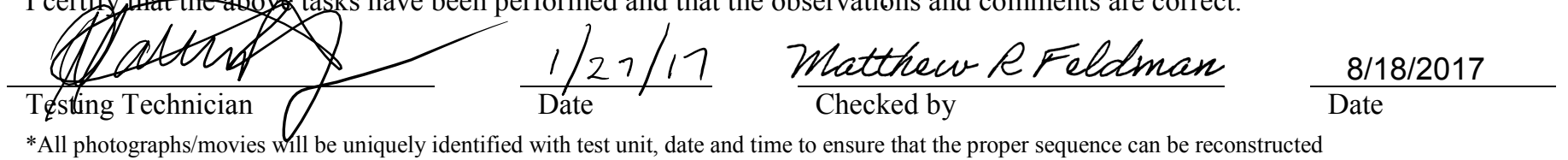

*All photographs/movies will be uniquely identified with test unit, date and time to ensure that the proper sequence can be reconstructed

ORNL/NTRC-074, Rev. 0 November 2016

A-4 


\section{TEST FORM 4 - Thermal Test Data Sheet}

TASK

Record the temperature in the furnace every 30 seconds for the duration of the test:

\begin{tabular}{|c|c|c|}
\hline Time & Thermocouple $1{ }^{\circ} \mathrm{C}$ & Thermocouple $2{ }^{\circ} \mathrm{C}$ \\
\hline 0 & 830 & 849 \\
\hline 30 & 851 & 855 \\
\hline 100 & 851 & 863 \\
\hline 30 & 850 & 861 \\
\hline 200 & 849 & 861 \\
\hline 230 & 849 & 861 \\
\hline 300 & 849 & 861 \\
\hline 330 & 849 & 861 \\
\hline 400 & 849 & 860 \\
\hline 430 & 850 & 861 \\
\hline 500 & 850 & 860 \\
\hline 530 & 851 & 860 \\
\hline 600 & 852 & 860 \\
\hline 630 & 852 & 860 \\
\hline 700 & 853 & 860 \\
\hline 730 & 853 & 861 \\
\hline 800 & 854 & 860 \\
\hline 830 & 854 & 860 \\
\hline 400 & 854 & 860 \\
\hline 930 & 855 & 861 \\
\hline 1000 & 855 & 861 \\
\hline
\end{tabular}

Comments: $1 / 26 / 2017 C 2: 34 \mathrm{pm}$ (stard) To pillowed after test. TCl: BF $3874 \quad T \angle 2=B F 3 F 05$

I certify that the above tasks have been performed and that the observations and comments are correct.

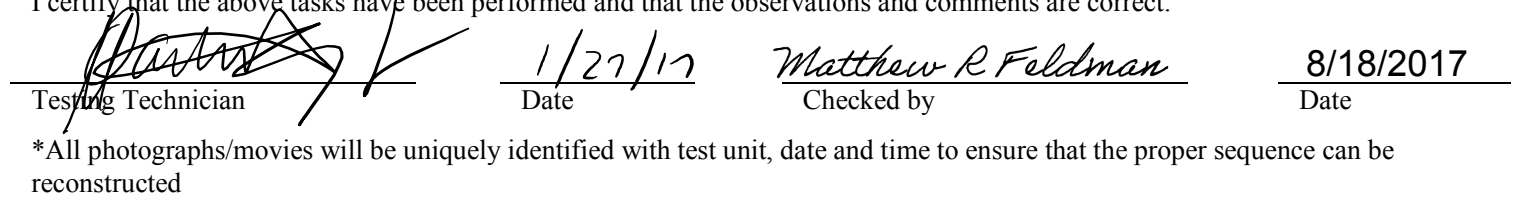




\section{LEAK TEST REPORT}

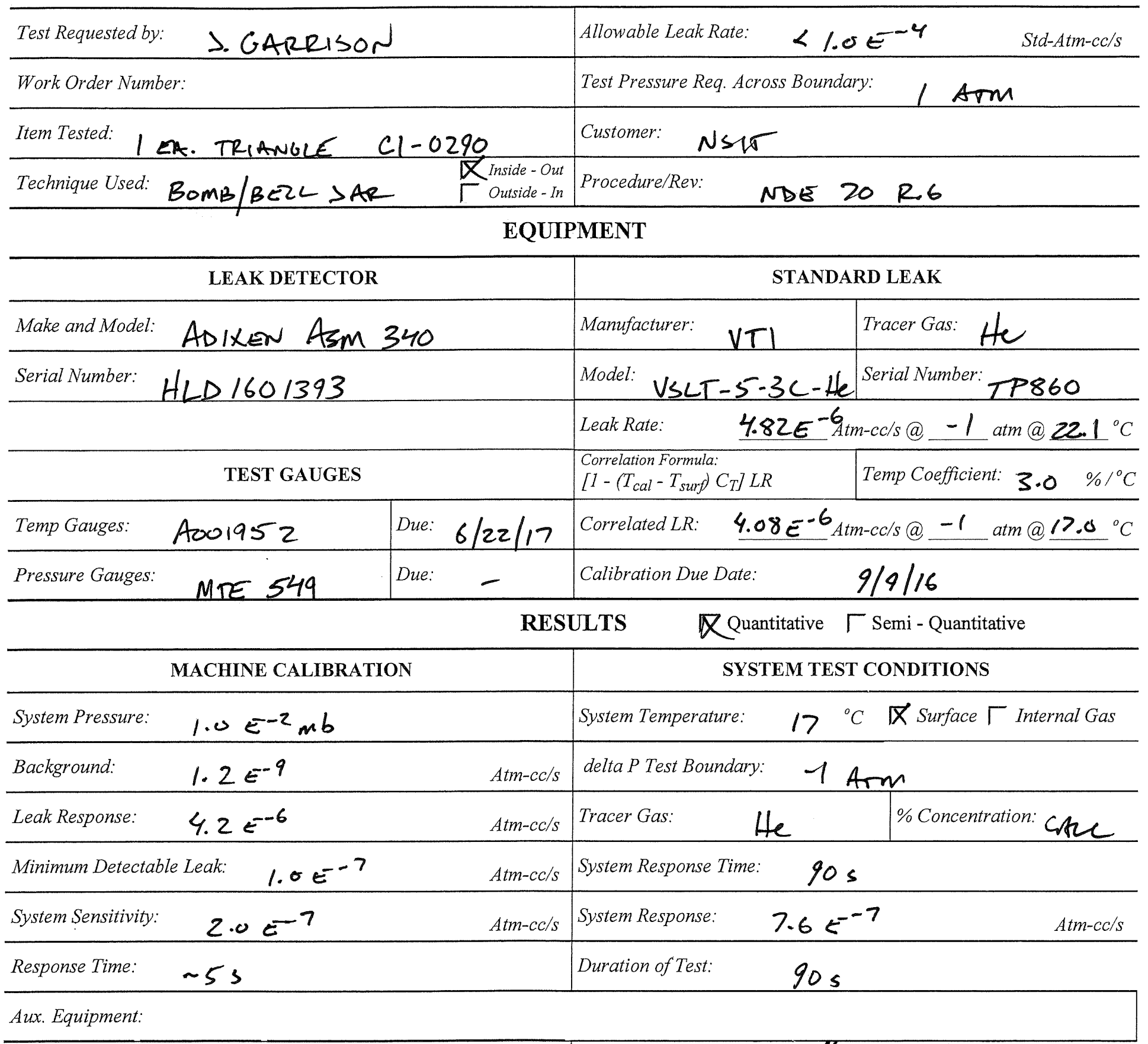

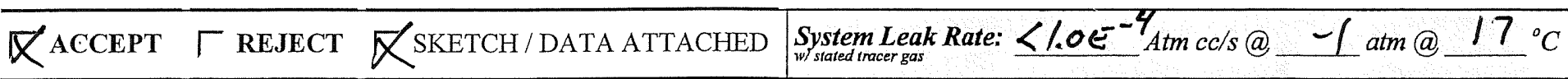
COMMENTS:

$$
\begin{aligned}
& \text { FINE LT } \\
& \text { POST HEAT TEST }
\end{aligned}
$$

Test Conducted By: (Print \& Sign Name/Level):

Date $2 / 1 / 12$
Time:

$1: 40$ 


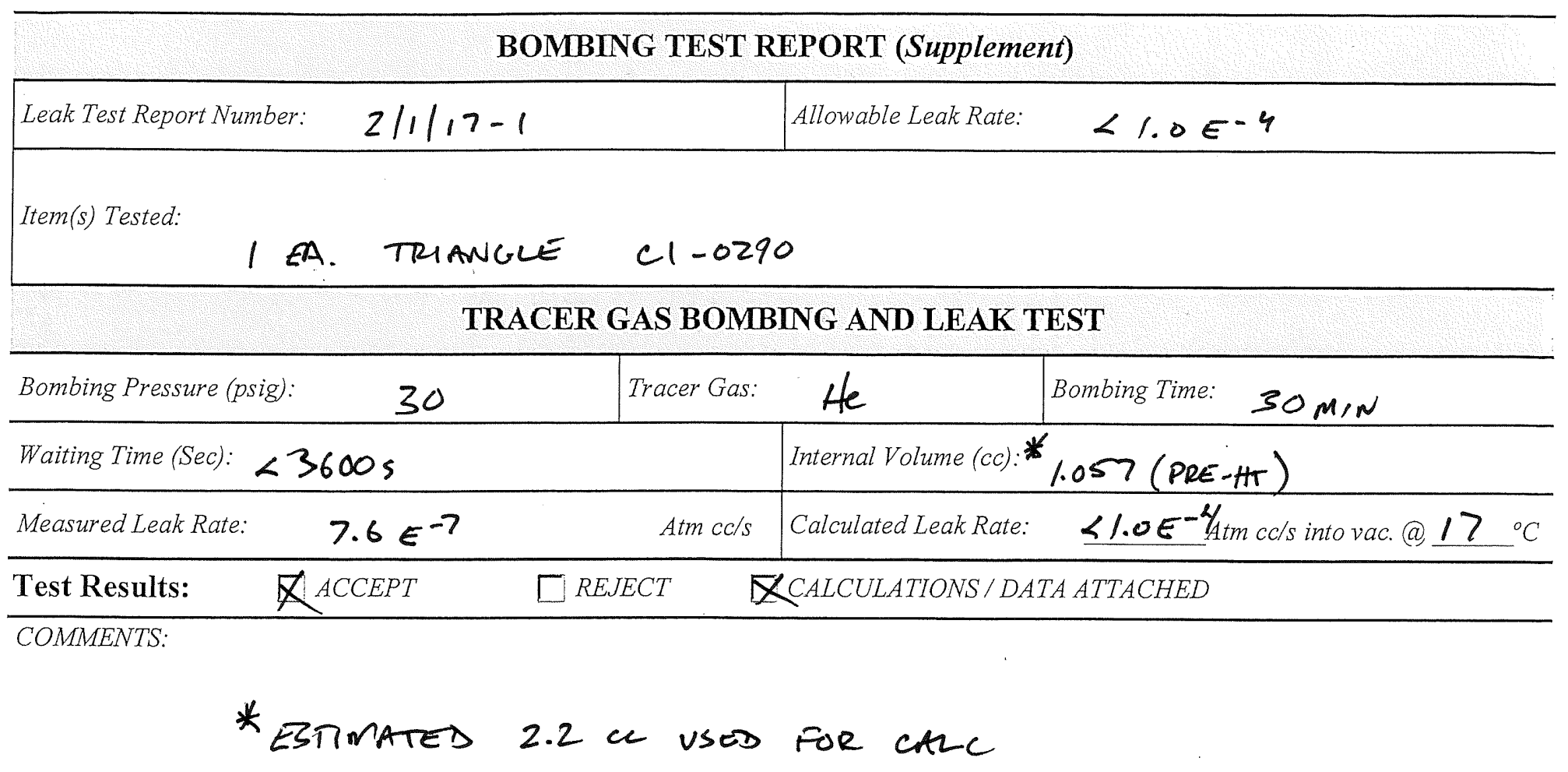

Test Conducted By: (Print \& Sign Name/Level):

E.Vrote zicistribl LII

Date:

$2 / 1 / 17$ 


\section{LEAK TEST REPORT - BUBBLE TEST}

\begin{tabular}{|c|c|}
\hline Test Requested by: D. GARRBSON & Customer: \\
\hline Work Order Number: & Procedure: NDE $>0 R 6$ \\
\hline Item Tested: 1 et TRIANGLE C1-0290 & Test Pressure Required: $15 * \mathrm{Hg}$ \\
\hline Technique Used: VAC BOX & Liquid Media Used: IMmersit UM $200 @ 20 \%$ \\
\hline Test Gas Used: V Ve & Liquid Applicator Type: IMners 1 on \\
\hline Inspection Light Intensity: $\quad>100 \mathrm{Fe}$ & Post Cleaning Method: \\
\hline Other Apparatus Used: & \\
\hline
\end{tabular}

\section{Direct Pressure Technique $\square$}

\section{Vacuum Pressure Technique $\mathbb{X}$}

Component Limits of Test:

Component Test Site $\quad 7606 \mathrm{~A}$

\begin{tabular}{|c|c|c|c|c|c|c|c|}
\hline \multicolumn{3}{|c|}{ Gauges } & \multicolumn{2}{c|}{ Test Pressure } & \multicolumn{2}{c|}{ Temperature } \\
\hline \multirow{2}{*}{ Mfg } & ID No & $\begin{array}{c}\text { Calibration } \\
\text { Date }\end{array}$ & Range & Beginning & End & Beginning & End \\
\hline & Aoo2124 & $8 / 11 / 16$ & $0-30^{\prime \prime} \mathrm{Hg}$ & $15^{\prime \prime} \mathrm{Hg}$ & $15^{\prime \prime} \mathrm{Hg}$ & $17^{\circ} \mathrm{C}$ & $17^{\circ} \mathrm{C}$ \\
\hline & & & & & & \\
\hline
\end{tabular}

Temperature Measuring Device

\begin{tabular}{|l|l|l|l|}
\hline Mfg. omeZA & Model HA804 & Range K-TYPC & I.D.Number A001952 \\
\hline
\end{tabular}

\begin{tabular}{lll}
\hline RESULTS $\square$ PACCEPT \\
\hline
\end{tabular}

Comments:

$$
\text { Post Hat TEST }
$$

Test Conducted By: (Print \& Sign Name/Level):
Date:

$2 / 1 / 17$ 


\section{APPENDIX C. WELD INSPECTION REPORT}


Triangle Encasement Components (SI Units Version)

SYSTEM

C1-0288, C1-0289, C1-0290

DRAWING NUMBER

SK-NMP-20160616-01

WELD NUMBER

W-1

SHOP

WELD SPEC.

GT88-A (PP), *GT88-1 (PP)

REDC 7930

INSP. SPEC.

FHRD-T-NDE 21 Rev 2

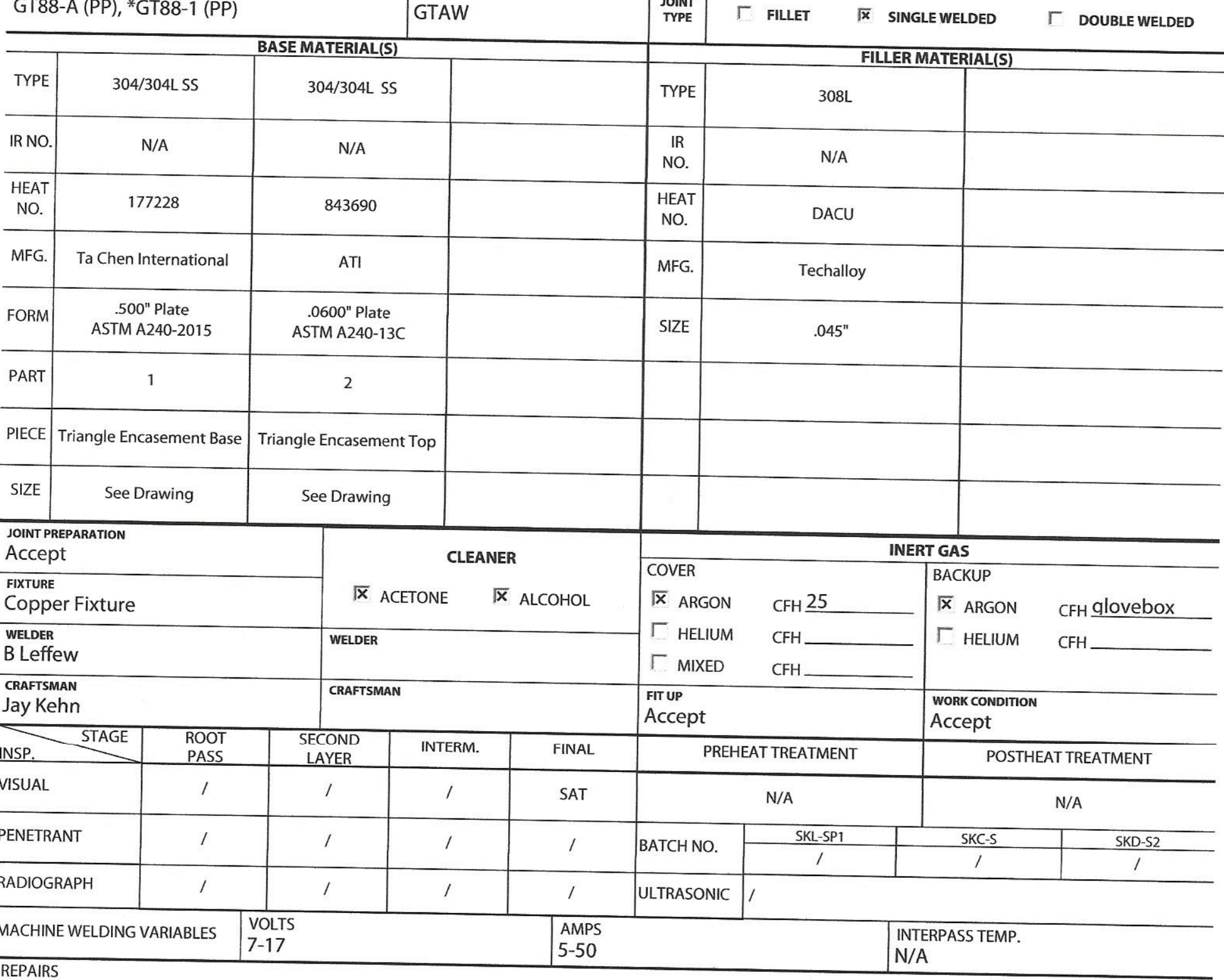

REMARKS

*Weld filler metal used only if necessary.

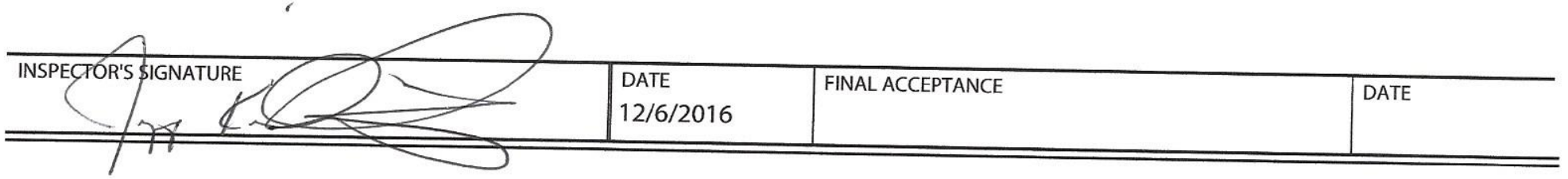




\section{APPENDIX D. LEAK TESTER CERTIFICATION}




\title{
OAK RIDGE NATIONAL LABORATORY
}

MANAGED BY UT-BATTELLE FOR THE DEPARTMENT OF ENERGY

\section{NDT Personnel Qualification and Record of Certification}

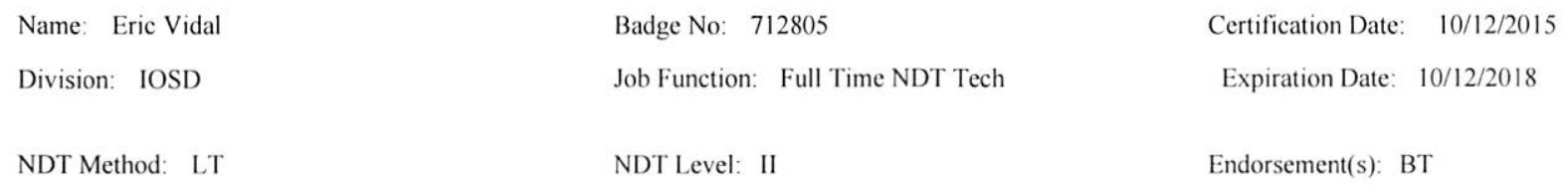

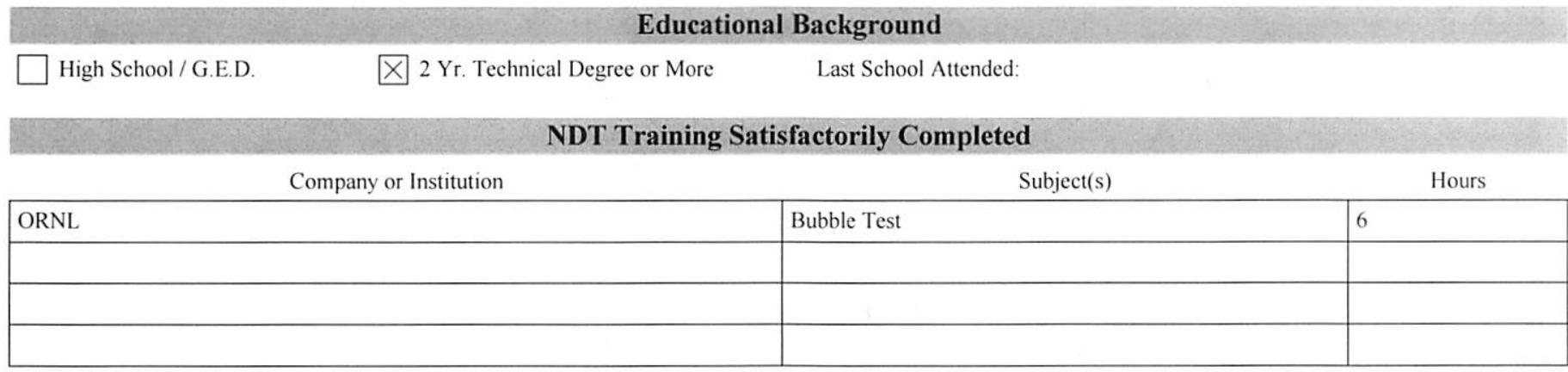

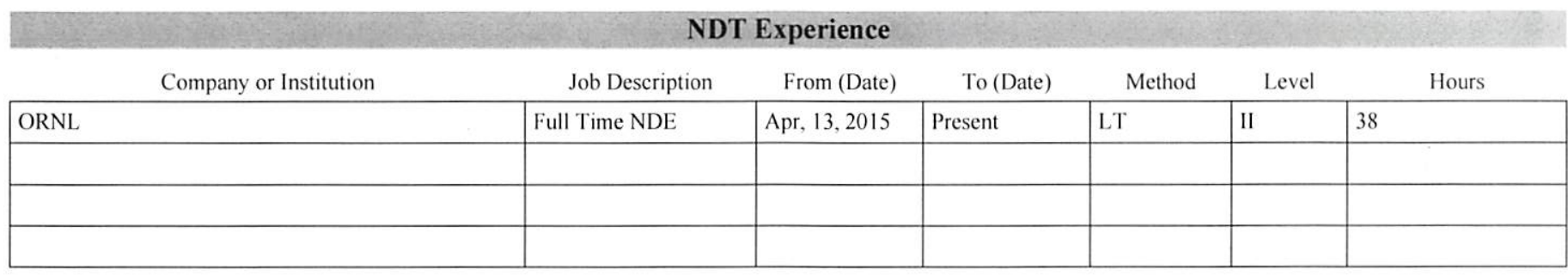

\section{Examination Results}

\begin{abstract}
INITIAL EXAM
General Knowledge

Procedure Specific

Hands-On-Practical

Composite Score:
\end{abstract}

\begin{tabular}{|c|c|}
\hline Date & No. Questions \\
\hline Oct. 12,2015 & 40 \\
\hline Oct. 7, 2015 & 30 \\
\hline Oct. 7, 2015 & 20 \\
\hline 92 & \\
\hline
\end{tabular}

Pass / Fai

Administered by

REQUALIFICATION EXAM

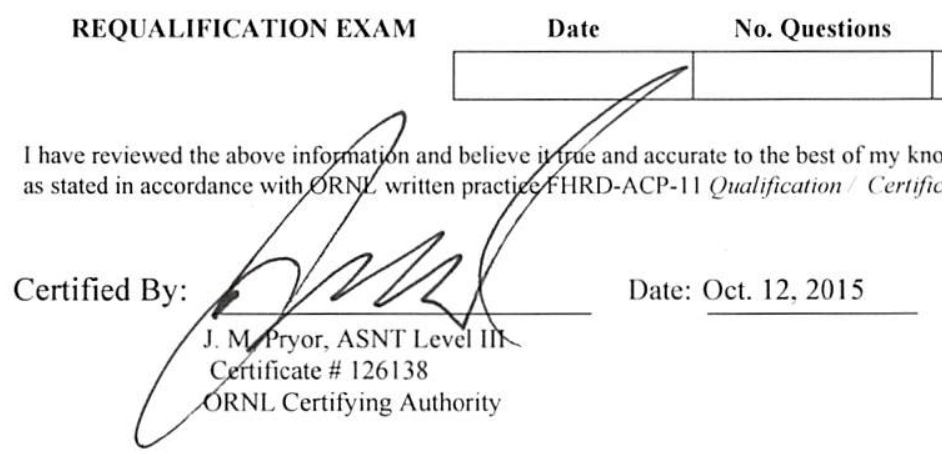

ate

No. Questions

\begin{tabular}{|l}
$\mathrm{P}$ \\
$\mathrm{P}$ \\
$\mathrm{P}$ \\
\hline
\end{tabular}

J. M. Pryor, ASNT Level III

J. M. Pryor, ASNT Level III

J. M. Pryor, ASNT Level III

Authorized By:

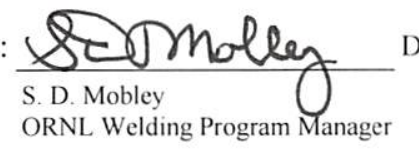

Date: Oct. 12, 2015

Note: This certification is void on the indicated Expiration Date, upon termination of current employment, or revocation by employer, whichever comes first. Certification examinations and full training records are on file at ORNL building 7003; viewable upon request. 


\title{
OAK RIDGENATIONAL LABORATORY
}

\section{MANAGED BY UT-BATTELLE FOR THE DEPARTMENT OF ENERGY}

\section{NDT Personnel Qualification and Record of Certification}

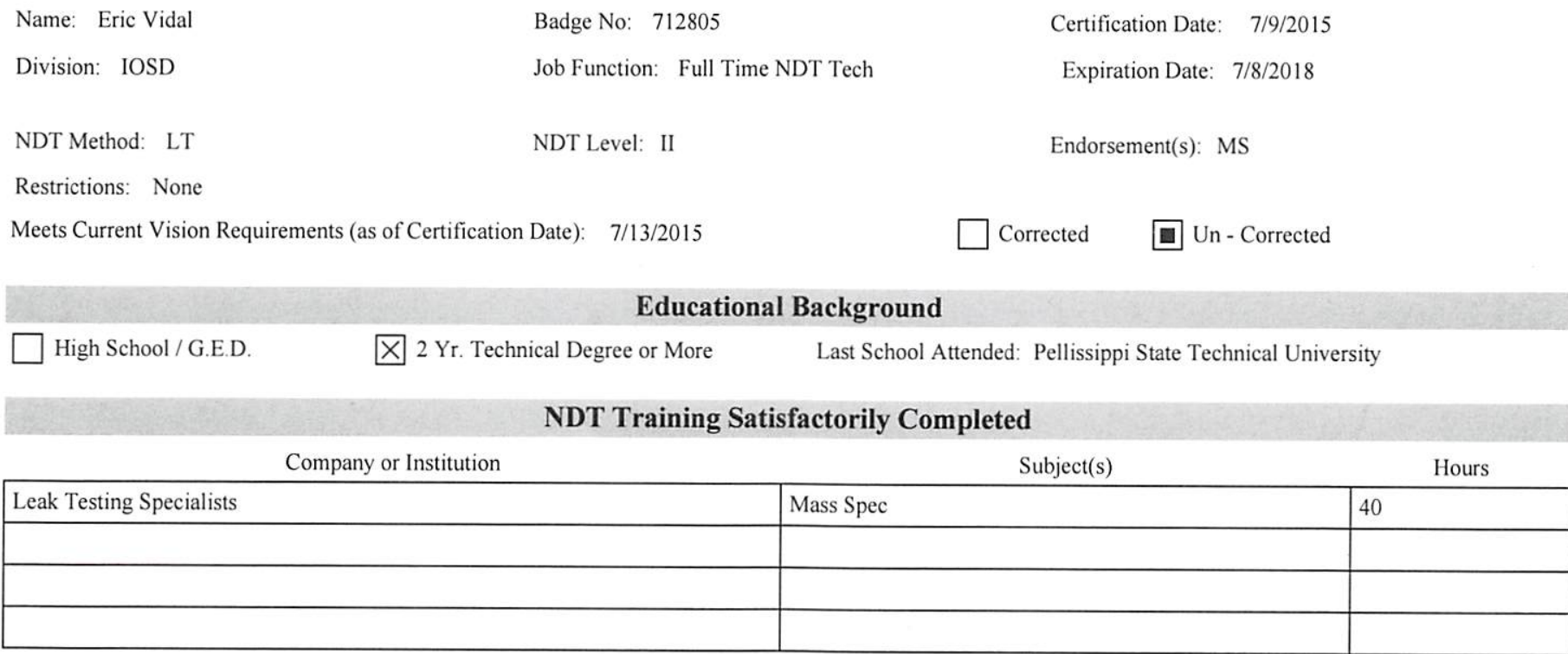

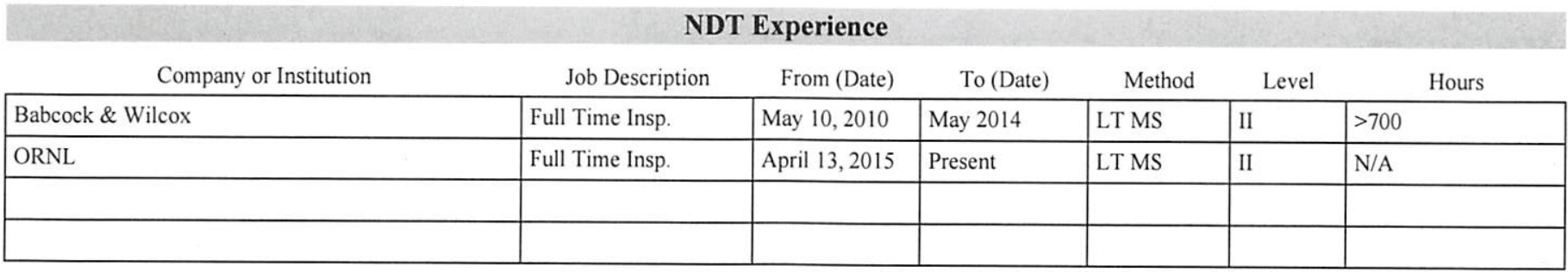

\section{Examination Results}

\begin{abstract}
INITIAL EXAM
General Knowledge

Procedure Specific

Hands-On-Practical

Composite Score:
\end{abstract}

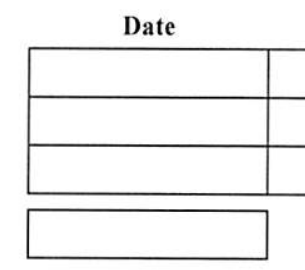

No. Questions

Pass / Fail

Administered by

REQUALIFICATION EXAM

\begin{tabular}{|l|l|l|l|}
\multicolumn{1}{r}{ Date } & \multicolumn{2}{c}{ No. Questions } & \multicolumn{1}{c|}{ Administered by } \\
\hline $7 / 9 / 2015$ & 30 & Pass & Jeff Pryor, ASNT Level III Cert. \#126138 \\
\hline
\end{tabular}

I have reviewed the above information and belieye it true and accurate to the best of my knowledge. I hereby certify this employee meets the requirements of NDT technician as stated in accordance with ORND written practice FHRD-ACP-11 Qualification/Certification Requirements for NDE Examiners and Recommended Practice No. ASNT SNT-TC-1A.

Certified By:

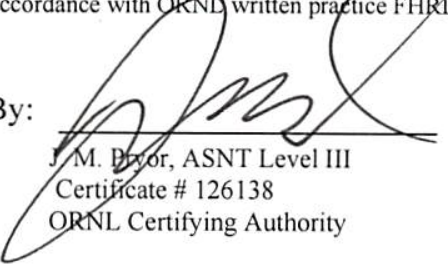

Date: $7 / 9 / 2015$

Authorized By:

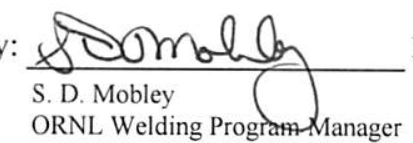

Date: $7 / 9 / 2015$

Note: This certification is void on the indicated Expiration Date, upon termination of current employment, or revocation by employer, whichever comes first. Certification examinations and full training records are on file at ORNL building 7003; viewable upon request. 


\section{The American Society for Nondestructive Testing, Inc.}

Be it known that

\section{Jeff M Pryor}

has met the established and published Requirements for Certification by ASNT as

NDT Level III

in the following Nondestructive Testing Methods:

\begin{tabular}{|c|c|c|}
\hline Method & Issue Date & Expiration Date \\
\hline Leak Testing & $6 / 15$ & $6 / 20$ \\
\hline Liquid Penetrant Testing & $6 / 15$ & $6 / 20$ \\
\hline Magnetic Particle Testing & $6 / 15$ & $6 / 20$ \\
\hline Radiographic Testing & $6 / 15$ & $6 / 20$ \\
\hline Ultrasonic Testing & $6 / 15$ & $6 / 20$ \\
\hline Visual Testing & $6 / 15$ & $6 / 20$ \\
\hline
\end{tabular}

126138

Certificate Number

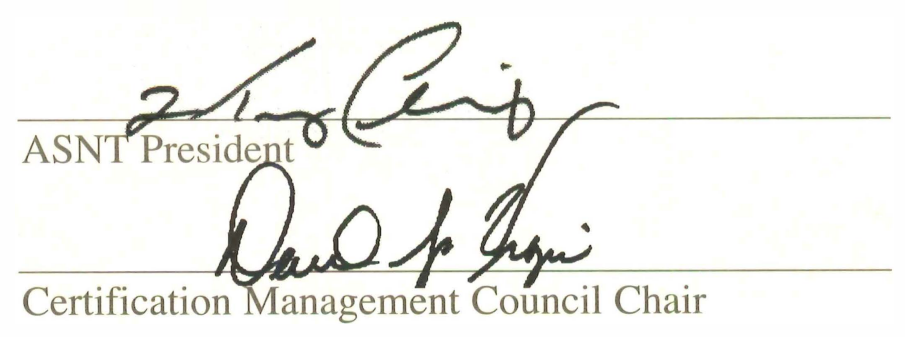

This certificate is the property of ASNT, is not official without ASNT's raised gold seal and is subject to revocation prior to the listed expiration date. This certificate should be verified on the ASNT website or by contacting the ASNT Technical Services Department. 


\section{APPENDIX E. LEAK TESTING PROCEDURE}

ORNL Leak test procedure not available for public release. Procedure number is NDE 70, Rev. 6 
APPENDIX F. CALIBRATION RECORDS 
OAK RIDGE NATIONAL LABORATORY

METROLOGY DEPARTMENT

TEST REPORT

ITEM: $39.38 "$ LENGTH STANDARD

Serial Number: $\underline{\text { A001146 }}$

CUSTODIAN: M. FELDMAN

\begin{tabular}{|l|l|c|l|}
\hline & AS FOUND & REQUIREMENT & INSPECTION METHOD \\
\hline LENGTH & $39.4000 / 39.4099$ & 39.38 & CMM \\
\hline
\end{tabular}

Temperature: $68^{\circ} \mathrm{F}$

Date $11 / 03 / 11$

Inspector '024294

Date Due 11/03/16

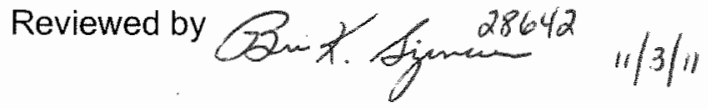

NATIONAL INSTITUTE OF STANDARDS AND TECHNOLOGY TRACEABILITY

ESTABLISHED THROUGH ORNL PRIMARY STANDARDS

Standards used:

ID\#

Calibration Due Date

M212632

$5 / 19 / 14$ 


\section{Certificate of Calibration}

ISO 9001:2008 (10101/2)

\section{Everett Service Center}

\section{Certificate Number: 291652}

Data Type:

Found-Left

Result Summary: In Tolerance

Manufacturer: Fluke

Model:

52 II

Serial Number: $\quad 36370410 W S$

Description: Thermometer

$\begin{array}{rr}\text { Calibration Date: } & \text { 07-Nov-2016 } \\ \text { Calibration Due: } & 07-N o v-2017 \\ \text { Certificate Date: } & 07-N o v-2016 \\ \text { Temperature: } & 24.2{ }^{\circ} \mathrm{C} \\ \text { Humidity: } & 35.9 \%\end{array}$

Revision:

Country:

GA

RMA:

31143929

This calibration is traceable to the International System of Units (SI), through National Metrology Institutes (NIST, PTB, NRC, NPL, etc.), ratiometric techniques, or natural physical constants. This certificate applies only to the item identified and shall not be reproduced other than in full, without the specific written approval by Fluke Corporation. Calibration certificates without signature are not valid. The calibration has been completed in accordance with Fluke Electronics Corporation Quality System Document 111.0 Revision 118 8/2014 and/or Fluke 17025 Quality Manual QSD 111.41 Revision 005 9/2014.

The Data Type found in this certificate must be interpreted as:

- As - Found Calibration data collected before the unit is adjusted and / or repaired.

- As - Left Calibration data collected after the unit has been adjusted and / or repaired.

- Found-Left Calibration data collected without any adjustment and / or repair performed.
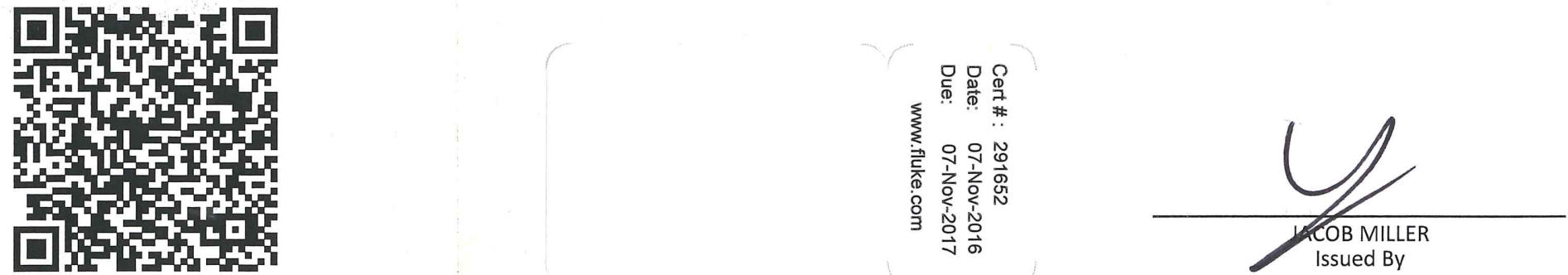
Standards Used

Asset

B1322

\section{Description}

Fluke 5520A Calibrator
Date of Calibration: 07-Nov-2016

Cal-Date Cal-Due

27-Sep-2016

27-Sep-2017 
Job\# 3054371

Date: $1 / 24 / 17$
Technical Support Department Instrument Data Continuation Sheet
Tech: 30220

Std: A001277

M210101

A002021

\begin{tabular}{|c|c|c|c|c|c|}
\hline Furnace & Standard & \multicolumn{4}{|c|}{ UUT Reading } \\
\hline & Type S & BF3874 & Error & BF3F05 & Error \\
\hline $\mathbf{2 1 . 5}$ & $\mathbf{2 1 . 5}$ & 20.9 & -0.6 & 21.1 & -0.4 \\
\hline $\mathbf{7 5 0 . 0}$ & $\mathbf{7 5 4 . 1}$ & 755.0 & 0.9 & 754 & -0.1 \\
\hline $\mathbf{8 0 0 . 0}$ & $\mathbf{8 0 3 . 5}$ & 804.5 & 1.0 & 803.6 & 0.1 \\
\hline $\mathbf{8 5 0 . 0}$ & $\mathbf{8 5 4 . 0}$ & 855.0 & 1.0 & 854.4 & 0.4 \\
\hline $\mathbf{9 0 0 . 0}$ & $\mathbf{9 0 4 . 3}$ & 905.4 & 1.1 & 905.1 & 0.8 \\
\hline $\mathbf{9 5 0 . 0}$ & $\mathbf{9 5 5 . 4}$ & 956.9 & 1.5 & 956.3 & 0.9 \\
\hline
\end{tabular}




\begin{tabular}{|c|c|c|}
\hline $\begin{array}{c}\text { Unit Under Test Information } \\
\text { Manufacturer: Oak Ridge National Laboratory } \\
\text { Description: Type S Thermocouple Dual Junction } \\
\text { Model Number: N/A } \\
\text { Serial Number: N/A } \\
\text { Asset / ID Number: A001277 } \\
\text { Custodian: Anthony D Mcbee } \\
\text { Work Order Number: } 2016002594\end{array}$ & $\begin{array}{l}\text { Customer Information } \\
\text { Anthony D Mcbee } \\
\text { Building: } 2547 \\
\text { Room: } 002 \\
\text { Mail Stop: } 6300 \\
\text { 865-574-6293 }\end{array}$ & $\begin{array}{l}\text { Test Information } \\
\text { Certificate Number: 2016002594 } \\
\text { Overall Result: Pass } \\
\text { Performed on: } 1 / 18 / 2017 \\
\text { Next Cal Due: } 1 / 18 / 2018 \\
\text { Performed by: Greg Strickland } \\
\text { Environment: } 23.4^{\circ} \mathrm{C} \quad 46.8 \% \mathrm{Rh} \\
\text { Received: In Tolerance }\end{array}$ \\
\hline \multicolumn{3}{|l|}{ Notes: } \\
\hline ||||||||||||||||||||||||||||||||||| & & 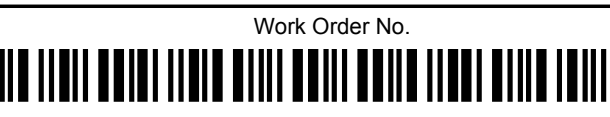 \\
\hline
\end{tabular}

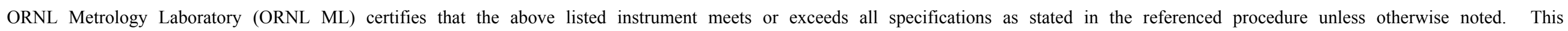
Report of Calibration applies only to the item being calibrated, identified above.

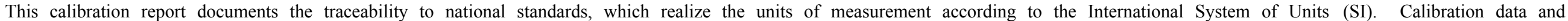

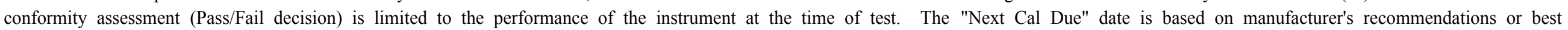

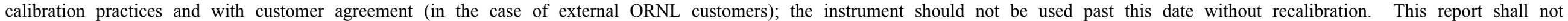

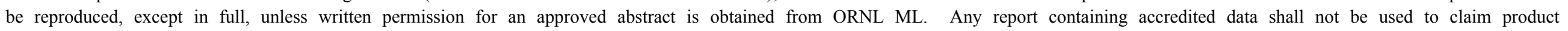
certification, approval, or endorsement by NVLAP, NIST, or any agency of the Federal Government. Calibration reports without authorizing signature(s) are not valid.

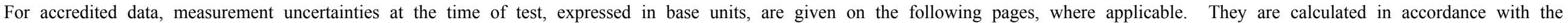

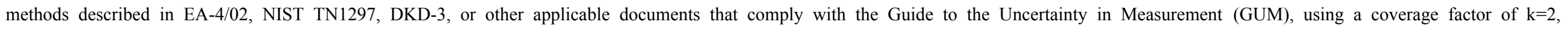

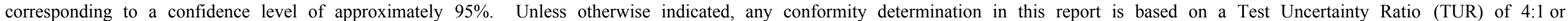

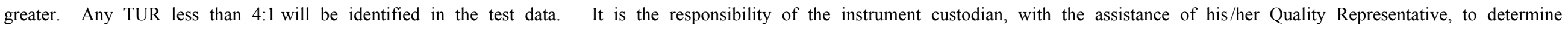
whether this level of confidence for the determination of conformance is adequate for the intended use of this instrument.

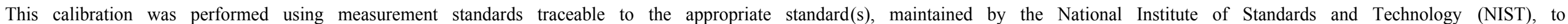

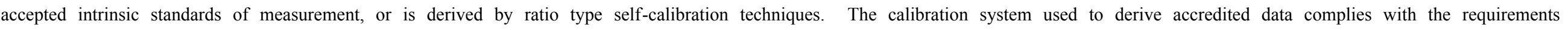
of NIST Handbook 150, ANSI/NCSL Z540.1-1999 (R2002), ISO/IEC 17025.

\begin{tabular}{|c|c|c|c|}
\hline \multicolumn{4}{|c|}{ Standards Used } \\
\hline ID & Description & Service Date & Due Date \\
\hline 0078611 & Isotech MicroK-100 Thermometry Bridge & $6 / 2 / 2016$ & $6 / 2 / 2017$ \\
\hline 0078621 & Isotech ITL-M-17673 Silver Freeze Point Cell & $9 / 4 / 2009$ & $9 / 4 / 2017$ \\
\hline A001412 & Rosemount 162CE SPRT & $11 / 15 / 2016$ & $2 / 15 / 2017$ \\
\hline
\end{tabular}




\section{FOUND_LEFT}

Procedure used: Manual Data File Reader, Rev. 1.0

\begin{tabular}{|c|c|c|c|c|c|c|c|c|c|}
\hline Test Data & & & & & & & & & \\
\hline $\begin{array}{c}\text { UUT Range / } \\
\text { Comment }\end{array}$ & $\begin{array}{l}\text { Standard } \\
\text { Reading }\end{array}$ & $\begin{array}{l}\text { Standard } \\
\text { Modifier }\end{array}$ & $\begin{array}{c}\text { UUT } \\
\text { Reading }\end{array}$ & $\begin{array}{c}\text { UUT } \\
\text { Tolerance }\end{array}$ & $\begin{array}{l}\text { UUT } \\
\text { Error }\end{array}$ & $\%$ Tol & $\begin{array}{c}\text { Measurement } \\
\text { Uncertainty }\end{array}$ & Accred & Test Status \\
\hline
\end{tabular}

INITIAL INSPECTION

Instrument was received in good, functional condition.

Procedure used: Manual Data

UUT Specification is based on (Type S Special Grade +/- 0.6 Deg C or $0.1 \%$ WIG Plus Indicator Specification of +/- 0.6 Deg C) ist UUT UUT

Measurement

Standard Temperature

Uncertainty

(Deg C)

(Deg C)

(Deg $C)$

Specification

231.97

231.7

(Deg C)

(Deg C)

418.97

594.01

419.0

1.20

593.2

1.20

961.78

961.2

$-0.3$

1.26

A001277-B

231.99

231.7

1.56

419.05

231.7
419.1

593.1

1.20

594.01

961.3

1.20

$-0.3$

1.56

$-0.5$

* Test Uncertainty Ratio < $4: 1$

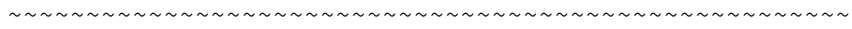

-- End of measurement results--

Approved By: Greg Strickland 1/18/2017

Technical Manager 